\title{
TASMANIA'S EUCALYPTS: THEIR PLACE IN SCIENCE
}

\author{
by Brad M. Potts and James B. Reid
}

(with four text-figures and 13 plates)

\begin{abstract}
PotTs, B.M. \& REID, J.B., 2003 (1 9:xii): Tasmania's eucalypts: their place in science. Papers and Proceedings of the Royal Society of Tasmania 137: 21-37. https://doi.org/10.26749/rstpp.137.21 ISSN 0080-4703.

School of Plant Science and CRC for Sustainable Production Forest ${ }_{\mathrm{ry}}$, University ofTasmania, Private Bag 55, Hobart, Tasmania 7001, Australia. (BMP*, JBR) *Author for correspondence.

While representing only 29 of the more than 700 eucalypt species, those on the island of Tasmania have a unique place in the history and scientific discovery of this iconic genus. Eucalypts entered written history when Abel Tasman discovered Tasmania in 1642 and the type specimen for the genus, Eucalyptus obliqua L'Hér., was collected from Bruny Island in 1777 during Cook's third voyage. The discovery of some of the endemic taxa was linked with the French expedition searching for La Pérouse in 1792-1793, and the return of the type specimens to France was a great triumph against adversity. Nearly half a century later British botanists contributed to the discovery of the Tasmanian eucalypts with colonial collectors sending specimens to Kew Gardens, and with Australian-based botanists completing the pioneering stages of botanical discovery in the early 1900s. Botanists in Tasmania then led experimental approaches to understanding their evolution, ensuring a place for the island's eucalypts in twentieth-century science. The first major study of eucalypt chromosomes and cell division was undertaken with the Tasmanian eucalypts in the 1930s. The post-war decade saw the establishment of many of the lines of scientific enquiry pursued today, through the research of pioneering Tasmanian scientists such as $\mathrm{H}$. Newton Barber and the recently deceased Bill Jackson, both of whom served as Professor of Botany at the University of Tasmania. Their studies of the roles of natural selection and hybridisation in the evolution of tree genera led to outstanding work on the nature and origins of clinal variation. Molecular techniques have now allowed many of the questions posed by the early work of Jackson and Barber to be addressed. However, just as old questions are answered, new questions arise as genomic studies on this unique Australian genus open a new era of scientific discovery.
\end{abstract}

Key Words: Eucalyptus, Tasmania, history, chromosomes, natural selection, hybridisation, clinal variation, quantitative genetics, molecular genetics.

\section{INTRODUCTION}

Eucalypts, in the broad sense, include species from the genera Angophora, Corymbia and Eucalyptus (see Ladiges \& Udovicic 2000, Steane et al. 2002) and are native only to Australia and islands to its immediate north (Eldridge et al. 1993). They are a dominant component of Australia's forests and woodlands, and are critically important to biodiversity (Williams \& Woinarski 1997) and commercial forestry (Eldridge et al. 1993, Turnbull 1999). Eucalypts are also Australia's major germplasm contribution to the world and are now the most-planted hardwood trees globally, with over 12 million hectares of plantation established (Turnbull 1999). Only29 of the more than 700 species of eucalypts currently recognised are native to the island of Tasmania (Williams \& Potts 1996) and only two of the 13 major evolutionary lineages recognised by Brooker (2000) are present. Tasmania, therefore, has neither the great taxonomic diversity of Queensland (Ladiges 1997) nor the floral diversity seen in Western Australia with thelarge red flowering species such as Corymbia ficifolia or Eucalyptus macrocarpa (Brooker \& Kleinig 1990). However, the island does have a group of species that have a unique place in the history and the scientific discovery of this typically Australian genus. Work by numerous scientists has given them a status within botanical, evolutionary and forestry research, far in excess of the number of species present on the island. The Tasmanian eucalypts have, for example, provided numerous insights into the evolution of trees (e.g., Barber \& Jackson 1957, Jackson 1960a, Potts \& Jackson 1986, Potts \& Reid 1988, McKinnon et al. 2001a). This paper is an account of the scientific discovery of these species and is a tribute to the contributions of the recently deceased Professor Bill Jackson and his predecessor Professor Newton Barber, who together initiated many of the current directions of research aimed at understanding eucalypt biodiversity and evolution in Tasmania.

\section{DISCOVERY OF THE GENUS 1642-1788}

The Tasmanian eucalypts were the first eucalypts clearly to be recorded by Europeans. It is possible that Portuguese (McIntyre 1977, Wallis 1988) or Dutch (e.g., voyage of the ships Pera and Arnhem in 1623, Schilder 1988) traders/explorers encountered eucalypts on the islands to the north of Australia, or even on continental Australia, in the sixteenth or early seventeenth century. However, the first written record appears to be from Abel Tasman's discovery of what he named Van Diemen's Land in 1642 (Zacharin 1978, Doughty 2000, Hay 2002) when he was in search of new trading lands and a shorter trade route to Chile for the Dutch East India Company. Brief landings were made while Tasman's ships, the Zeehaen and Heemskerck, were anchored in the lee of Visscher Island, off Cape Fredrick Henry on the northern end of Forestier Peninsula (pl. 1), between 1 and 4 December (Julian calendar) (Somerville 1964, Taylor 1973, Duyker 1992, Hay 2002).

The first European landing on Tasmanian soil was made on 2 December when Blackman Bay was charted. While the exact site of the first landing is not clearly recorded, Curtis \& Somerville (1948) argue that from the vegetation descriptions and collections, they probably landed at Boomer Creek on the western shore of Blackman Bay (pl. 2) at least sometime during the day. This is three kilometres from where the monument marking the landing is erected. The shore party, led by the commander of the Zeehaen, Pilot-major Francoys Visscher, noted the abundance of excellent timber, with several trees 60-65 feet to the lowest branches, and 


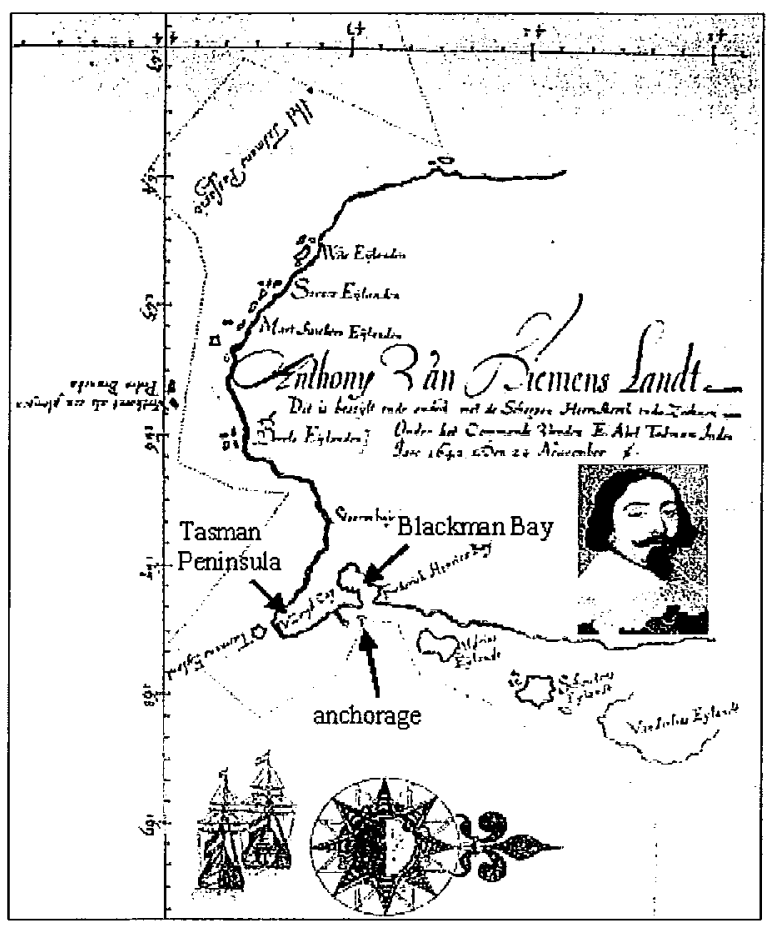

PLATE 1

Abel Tasman's chart showing the expedition's anchoring position in 1642 that is ENE of Tasman Bay on the Forestier Peninsula in the lee of Visscher Island. The nearby bay charted by the first landing party and labelled Frederick Hendricx Bay is the present day Blackman Bay where the first European landing on Tasmania and first recorded encounter of eucalypt trees occurred (from Duyker 1992). The inserts show the bust of Abel Tasman and the ships Zeehaen and Heemskerck.

brought back some fine gum that had dripped from the trees and resembled gum-lac (resin exuded by various trees and used in the manufacture of lacquer) (Walker 1891, Somerville 1964, Zacharin 1978, Duyker 1992). Zacharin (1978) considers their description almost certainly refers to Eucalyptus globulus Labill. (pl. 2). The landing party reported notches cut into the trees for climbing that were fully five feet apart, leading to the belief that the inhabitants of the island were very tall. They also reported animal tracks not unlike those of the tiger's claws on the ground beneath the trees.

The landing party was watching for attack from natives and commented upon the open nature of vegetation that allowed good visibility. This is consistent with the remnants of the dry, open forest of E. globulus, E. pulchella Desf., $E$. amygdalina Labill., $E$. ovata Labill. and $E$. viminalis Labill. that occur around the shores of Blackman Bay today. The following day the ship's carpenter swam through high seas to place a pole with the Company's mark and their Prince's flag in the middle of the Tasman Bay shore ( $\mathrm{pl}$. 3) and claimed the land as rightfully theirs (Duyker 1992: 15). The flag was planted "... near four high recognizable trees in the shape of a half-moon" which were no doubt $E$. globulus. The only other species currently growing at this exact spot are E. obliqua and the occasional E. tenuiramis Miq. (Peninsula form), but these are low trees and it is only E. globulus that stands out as a prominent tree.

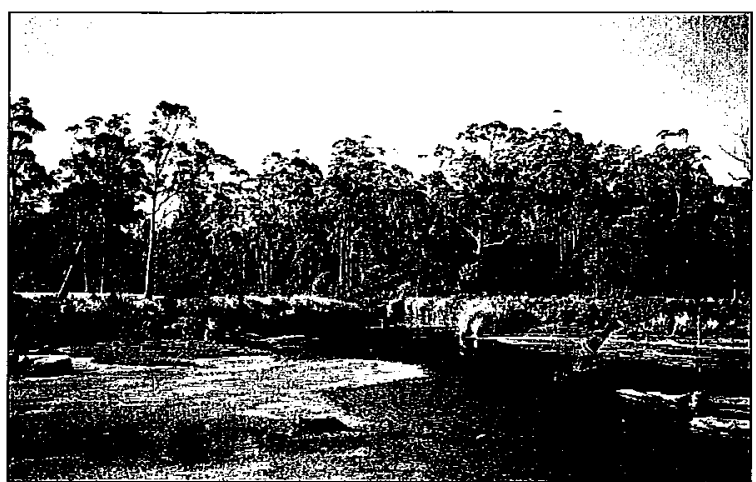

PLATE 2

Boomer Creek, in Blackman Bay, the site at which Abel Tasman's landing party is believed to bave collected water and edible herbs from the salt marsh on 2 December 1642 (Curtis \& Somerville 1948). This is likely to have been the site from where the first recorded observations of eucalypt trees were made. The trees on the left are Eucalyptus globulus; E. ovata grows near the creek and the forest on the billside is comprised of E. globulus, E. amygdalina, E. obliqua and E. viminalis.

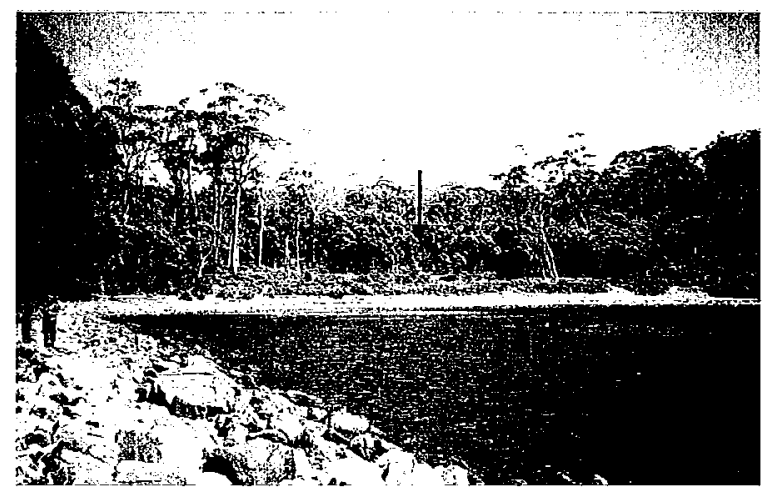

PLATE 3

Tasman Bay on Forestier Peninsula where Abel Tasman's carpenter, Pieter Jacobsz, swam ashore and planted a flag on 3 December 1642. The arrow shows the site of the monument marking the landing. A shallow reef shelters the bay and rough seas on the day prevented the long boat landing. The prominent tall trees along the entire foreshore in this general area are Eucalyptus globulus and from Tasman's description there is little doubt that the flag was placed in front of a tree of this species. The only other eucalypts at Tasman Bay today are small trees of $\mathrm{E}$. obliqua and the occasional E. tenuiramis.

While eucalypts had been collected from the east coast of mainland Australia during Captain James Cook's first voyage to Australia in 1770 (Hay 2002), the first eucalypt to be formally described was from Tasmania (L'Héritier de Brutelle 1788). It was a specimen of $E$. obliqua L'Hér. (pl. 4), collected from Adventure Bay on Bruny Island, and is the type specimen for the genus (Kantvilas 1996). The specimen was collected by William Anderson and his assistant David Nelson when Cook's two ships anchored at Adventure Bay from 26 to 30 January 1777 (Cook's ill-fated third voyage). Anderson, a surgeon, was the botanist and naturalist on the Resolution and had accompanied Cook on his previous voyage to the Pacific. He was interested in 


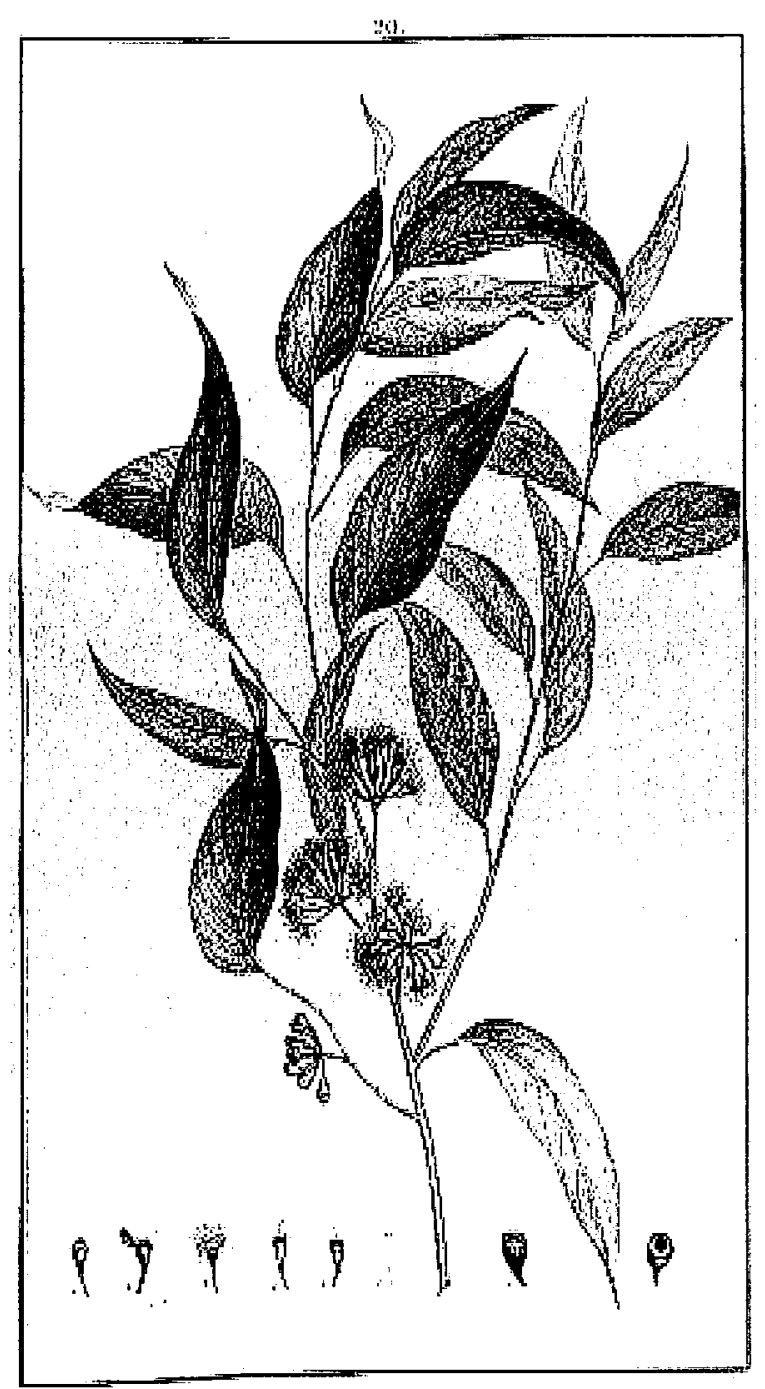

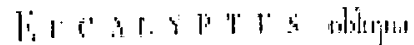

PLATE 4

The type specimen of the genus Eucalyptus was described by Charles L'Héritier de Brutelle in 1788 from a specimen of $\mathrm{E}$. obliqua collected on 26-30 January 1777 from Adventure Bay, Tasmania during Captain James Cook's third voyage to Australia. The drawing accompanying the description is by a famous botanical artist of the day, Pierre-Joseph Redouté. This work pre-dates by 16 years the 1804 drawing of $\mathrm{E}$. obliqua which Zacharin (1978) gives as the first known drawing of a eucalypt.

fragrant plants and was probably the first person to make detailed observations on the eucalypts, recording the possible presence of two species at Adventure Bay (Hay 2002). He died in the Behring Strait in 1778 and it was Nelson, the gardener and collector on the Discovery, who then became responsible for the plants and the return of the collections. Nelson was based at Kew Gardens in England and was sponsored by Sir Joseph Banks who was by then director of Kew Gardens, the world's key botanical centre at the time. The eucalypt specimens from this voyage were lodged at Kew Gardens but, along with specimens of previous voyages, remained undescribed for nearly a decade (see Hay 2002). It was the French botanist Charles L'Héritier de Brutelle who finally described one of these specimens in 1788 . L'Héritier, a magistrate by profession and an aristocratic supporter of the concept of the French Revolution, was a self-taught botanist with a particular interest in trees (Hay 2002). It was during his visit to London in 1786-87 that he worked on the extensive herbarium held by Banks and recognised the new genus with a name having a Greek root reflecting the unique cup-like operculum covering the flower (eu - well and calyptos - covered). L'Héritier was mysteriously murdered one night in the streets of Paris in 1800 (Zacharin 1978, Hall 1979).

Tasmanian seed of $E$. obliqua also appears to have produced the first eucalypt specimens to be grown in cultivation outside Australia (Somerville 1964, Doughty 2000). The seed was collected when the second ship of Cook's 1772 expedition, Adventure, under the command of Captain Tobias Furneaux, briefly landed at Bruny Island in March 1773 while en route to New Zealand. The head gardener at Kew seems to have planted seed after their return in July 1774 and a live specimen of $E$. obliqua was recorded to be growing at Kew in 1789 .

\section{THE FRENCH CONNECTION 1791-1806}

French botanists played an important role in the initial discovery of the Tasmanian eucalypt flora, providing the first major collections and descriptions of the Tasmanian eucalypt species (Kantvilas 1996). These early samples of eucalypts have a special place in science history because of their association with key events in world history (see Horner 1995 , Duyker \& Duyker 2001, Duyker 2003). They were part of the plant collection of the French botanist, Jacques Julien de Labillardière (pl.5), made during the Bruny D'Entrecasteaux expedition in the ships, Rechercheand Espérance (Labillardière 1800). The expedition visited Tasmania in both 1792 and again in 1793 and explored extensively the D'Entrecasteaux Channel region from anchorages at Recherche Bay (Pigsties Bay and Rocky Bay respectively). The French explorers were overwhelmed by the tall eucalypt forests of southern Tasmania (Labillardière 1800; Duyker \& Duyker 2001), with D'Entrecasteaux noting on his arrival in 1792:

... "It will be difficult for me to describe my feelings at the sight of this solitary harbour situated at the extremities of the world, so perfectly enclosed that one feels separated from the rest of the universe. Everything is influenced by the wilderness of the rugged landscape. With each step, one encounters the beauties of unspoilt nature, with signs of decrepitude; trees reaching a very great height, and of corresponding diameter are devoid of branches along the trunk, but crowned with an everlasting green foliage. Some of these trees seem as ancient as the world, and are so tightly interlaced that they are impenetrable. They support other trees of equal measurements which fall from old age, and nourish the soil with their decaying fragments. Nature, in all its vigour, and at the same time in decline, offers to the imagination something more imposing and picturesque than the sight of this same nature embellished by civilized man's industry. In wishing to conserve only its beauty, man has managed to destroy its charm and ruin its exclusive character - the one of being always old, and always new." (Duyker \& Duyker 2001: 32; see also Horner 1995: 69).

Labillardière appears to have collected $E$. cordata Labill., E. globulus Labill., E. ovata Labill., E. viminalis Labill., 


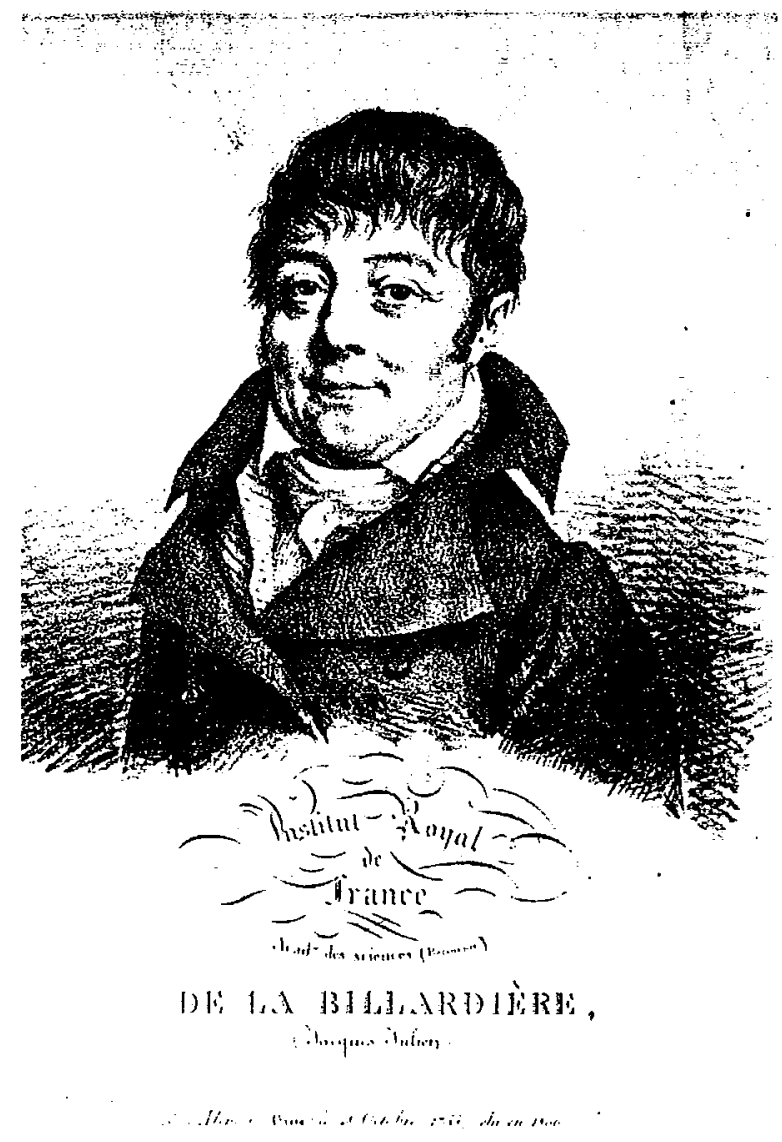

PLATE 5

The French naturalist Jacques-Julien Houtou de la Billardière (who signed as Labillardière) described five of the six eucalypt species be collected when the D'Entrecastaux expedition visited Tasmania in 1792 and 1793 (Labillardière 1800). The lithograph was produced by Julien L. Boilly, 1821 (Zacharin 1978).

E. amygdalina Labill. and E. pulchella Desf. during these two visits together with numerous other Tasmanian plant species (Duyker 2003). He also recorded some of the earliest encounters of Europeans with the Tasmanian Aborigines.

The D'Entrecasteaux expedition was undertaken in the middle of the French Revolution to search for the lost expedition of La Pérouse (see Horner 1995). It was a mercy mission, but ended up with a mini-revolution on board the ships with a major split between the royalist officers and the republican crew and many of the scientists, including Labillardière. After unsuccessfully scouring the Pacific for La Pérouse and the death of many of the crew, including D'Entrecasteaux, the ships were desperately in need of replenishments and repair. The expedition was forced to stop at the Dutch settlement of Surabaya on Java. The Dutch by this stage were at war with the revolutionary government in France and, at the request of royalist officers who remained faithful to the French Monarchy, the Dutch authorities jailed the republican crew and scientists. The expedition was forced to stay at Surabaya and eventually it became necessary for the royalist officers to sell the ships to the Dutch in repayment for the debts incurred by the expedition. The expedition's papers and natural history collections, including Labillardière's plant collection and the Tasmanian eucalypt specimens, were sent back to Europe with a convoy of Dutch merchant ships in 1795 accompanied by royalist members of the expedition. By this time, the French, under Napoleon Bonaparte, had conquered Holland so the English intercepted the convoy of its former ally at $\mathrm{St}$ Helena to prevent its merchandise falling into the hands of the French Republicans. The English transferred the papers and natural history collections from the D'Entrecasteaux expedition to an English warship for safe keeping for the "legitimate" king of France, Louis XVIII, who England still recognised. As it eventuated, this transfer was fortunate as the Dutch merchant ship originally carrying the expeditions crates subsequently sank in a squall.

Labillardière was eventually released from imprisonment in Java and returned to France in 1796 to write the first widely read account of the D'Entrecasteaux expedition, which was the republican version of events (Labillardière 1800). He also set about getting back his collection which, in the meantime, had been offered to Queen Charlotte, the Queen of England, by Louis XVIII and was being held by Sir Joseph Banks. While France and England were still at war, Labillardière did get his specimens, by what appears to be a ruse to which Banks was complicit, claiming that he (Labillardière) had received no salary whilst on the expedition and that the specimens were his rightful property not that of Louis XVIII (Horner 1995). The correspondence of Banks and Labillardière over this period is now famous for demonstrating how science can overcome the barriers of bureaucracy and politics (De Beer 1960).

On return of the specimens, Banks wrote:

..."I confess I wished much to learn from his specimens some of those discoveries in the natural order of plants which he must have made, but it seemed to my feelings dishonourable to avail myself even of the opportunity I had of examining them: I of course did not look them over: all will be returned to him. I shall not retain a leaf, a flower, or a Botanical idea of his Collection, for I have not possessed myself of any thing at all of his, that fortune committed to my custody" (to Antoine-Laurent de Jussieu, De Beer 1960: 65).

The return of the collection allowed Labillardière to produce the first publication covering the flora of Australia, issued in parts between 1804 and 1807 (Labillardière 1804-1807). As the collection from the D'Entrecasteaux expedition was considered part of Labillardière's private herbarium, it was sold to a private collector on his death in 1834 . It was subsequently bequeathed to the Grand Duke of Tuscany and is now held at the Museo Botanico at the University of Florence in Italy (Duyker 2003).

Labillardière described the Tasmanian eucalypts he collected in either 1799 (E. globulus - Labillardière 1800 - French version 1799) or 1806 (E. amygdalina, E. cordata, $E$. ovata, E. viminalis - Labillardière 1804-1807). There is some confusion in the literature as to the exact location from which some of these specimens were collected (e.g., $E$. ovata). He appears to have accessed some plant specimens collected by Leschenault de la Tour, the botanist on the Baudin expedition to Australia and Tasmania in 1800-1804, which were assimilated into his private herbarium (Kantvilas 1996). However, Labillardière (1800) recorded collecting several species of eucalypts to the northeast of their anchorage at Recherche Bay (in Pigsties Bay) on 23 April 1792 (E. amygdalina, E. globulus, $E$. nitida, E. obliqua, E. ovata and $E$. tenuiramis occur in this general area; Williams $\&$ 
Potts 1996). Recherche Bay is clearly the type locality of $E$. globulus (Tasmanian Bluegum), as Labillardière specifically recorded collecting E. globulus on 6 May 1792 by felling a tree in order to obtain flowers (which is strange as the species normally flowers between September and December; Williams \& Potts 1996), and designated the name for the species in his journal (Labillardière 1800). He was enthusiastic about the uses of the timber of the huge eucalypts observed at Recherche Bay and recorded that the carpenters had used planks of $E$. globulus to raise the gunwales of the ship's launch. While $E$. cordata was thought for many years to have been collected also from Recherche Bay, Labillardière (1800) specifically recorded collecting it from Penguin Island while the expedition was anchored in Adventure Bay, just prior to their departure from Tasmania in February 1793. The occurrence of a small population of $E$. cordata on this tiny island subsequently escaped the attention of naturalists until 1987 due to the inaccurate citation of the type locality in early taxonomic literature (see Potts 1988). Labillardière's clear account of its collection on the island and the small size of the extant population suggests that the type locality for this species may be one of the most accurately known for this period of botanical exploration in Australia (Potts 1988).

\section{THE FEVER TREE 1804 ONWARDS}

The Tasmanian floral emblem, E. globulus, was among the first eucalypts to be formally described. Following its discovery, it was rapidly spread throughout the world and it is the species by which most of the world first knew the genus Eucalyptus (Jacobs 1981, Doughty 2000, Lopez et al. 2001). There are now over 1.3 million hectares of $E$. globulus planted outside Australia (Doughty 2000) and about 0.4 million hectares of plantations established in Australia (Wood et al. 2001). It is the most important plantation eucalypt in temperate regions of the world where it is grown mainly for pulpwood production (Eldridge et al. 1993).

The primeval eucalypt forests of Tasmania were among the tallest forests in the world (Lewin 1906, pl. 6). Eucalyptus globulus was one of the tallest species observed, with huge trees up to $96 \mathrm{~m}$ (318 feet) in height recorded (Irby 1925; see also Hickey et al. 2000, Appendix 2). The proximity of native E. globulus to the coast ensured rapid use and knowledge of its timber by the early explorers and colonists (Lewin 1905, 1906, Kostoglou 1994a, b, 1995). The extensive waterways and sheltered harbours of southern Tasmania meant shipping facilities were ideal for transport of timber from these tall coastal forests at minimal cost. Huge logs of this species were transported to England where they were exhibited at The Great Exhibition of 1851 attracting great interest (Doughty 2000). The high-density timber was durable and resistant to the destructive Teredo sea-worm and E. globulus became prized for marine construction (Lewin 1905, 1906). By the late $1800 \mathrm{~s}$, giant trees $60-90 \mathrm{~m}$ high were regularly harvested from the forests of Tasman Peninsula, Bruny Island and the borders of the D'Entreacasteaux Channel and shipped throughout the world for wharf piles (100-120 feet in length and 20 inches square; $30-37 \mathrm{~m}$ by $0.5 \mathrm{~m}$ square).

By 1905, four million feet of piles had been supplied for British Admiralty contracts, including the naval docks at Dover (Lewin 1905). These huge E. globulus piles were acknowledged as "... the longest and biggest and the most durable that had ever reached British shores" (Lewin 1906:

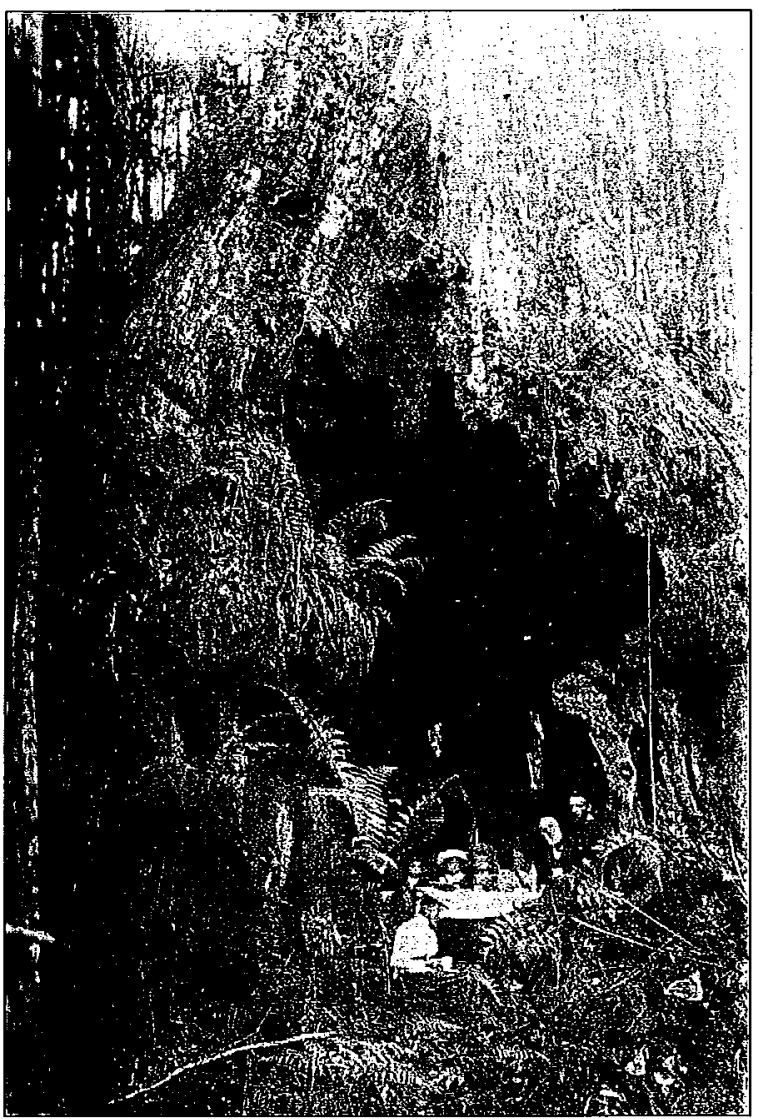

\section{PLATE 6}

The 'Big Ben' eucalypt tree at Port Esperence, southern Tasmania. Its height was nearly 250 feet $(76 \mathrm{~m})$; circumference $(5$ feet $\{1.5 \mathrm{~m}\}$ from ground level) was 95 feet $(29 \mathrm{~m})$ and the interior of the hollow measured 20 feet $x 25$ feet $(6 \mathrm{mx}$ $7.8 \mathrm{~m}$ ) (from Lewin 1906).

38). The strong durable timber was in demand for railway sleepers, street paving blocks and mining purposes. The Tasmanian eucalypts, E. globulus and E. obliqua, were a favourite with miners as they could bear great loads, and would not snap suddenly, but bend and always give warning before giving way (Lewin 1906). Even in warfare E. globulus proved superior with tests showing cannon balls would pierce, but not splinter its planks (Lewin 1906). By 1925, the Conservator of Forests, L. G. Irby (1925: 235), notes of the coastal forests around the southern Tasmanian waterways that "... sawmilling, splitting, felling, burning off, together with devastating bush fires, have all been taking heavy toll for a century past... Of the valuable timber species ... the Blue-gum is the only species at all scarce; regrowth of this species exists in many parts, but of mature trees the supply is now very low."

The spread of E. globulus plantations around the world was aided, not only by a great interest in the species as a timber tree, but also by the unpalatability of its juvenile foliage to cattle, sheep and goats (Jacobs 1981). There was also the unsubstantiated belief that, along with other eucalypts, it had properties that could result in the banishment of diseases such as malaria (Doughty 2000). E. globulus became known as the 'fever tree' (Lewin 1905), and in the latter half of the nineteenth century, millions of trees were planted to combat malaria in countries such as Algeria (Lewin 1906, Zacharin 1978). Such remedial effects of eucalypts were 
believed to be due to improved drainage through the fast growth as well as pharmacological properties of the bark and foliage. Scientific debate on this topic raged through the latter half of the nineteenth century, with E. globulus a central species in the debate. Simultaneously, cultivation of E. globulus specifically for timber and fuel production was rapidly expanding in many parts of the world. Its spread into California, for example, occurred at the time of the gold rush with it being widely promoted by government agencies and private investors as a source of construction timber and fuel wood (Doughty 2000). However, by the beginning of the twentieth century warping and splitting problems in the exotic-grown timber greatly reduced interest in its use for construction. Nevertheless, younger trees were still of interest as mine props and this was one of the main reasons for its early planting in Chile, near Lota.

Much E. globulus seed was distributed directly from Australia by, for example, Ferdinand von Mueller, the director of the Royal Botanical Gardens, Melbourne, who considered E. globulus the 'Prince of Eucalypts' (Doughty 2000: 51). France is believed to have been a key secondary distribution point (Zacharin 1978). E. globulus appears to have been initially grown in France from seed brought back from the Baudin expedition in 1804 (Horner 1995) and the species has been cultivated near major Mediterranean ports such as Toulon since 1813 (Doughty 2000). Indeed, Labillardière had strongly advocated the introduction into the south of France of several Australian species he had collected, including the mighty blue gum, and this was the subject of his last surviving letter, written in a trembling hand to the vice-president of the French Academie des Sciences in 1833 (Duyker 2003).

\section{TREES FROM THE COLONIES 1840-1860}

While eucalypts were rapidly introduced into the British Isles and the Tasmanian species had the reputation as the more frost-resilient (Zacharin 1978, Doughty 2000), it was not until nearly 50 years after the genus was discovered that English botanists described any of the Tasmanian eucalypt flora (Hall 1979, Kantvilas 1996). Five Tasmanian endemics - E. coccifera Hook. f., E. gunnii Hook. f., E. nitida Hook. f., E. urnigera Hook. f. and E. vernicosa Hook. f. - were described by Sir Joseph Dalton Hooker (pl. 7) who replaced his father, Sir William Jackson Hooker, as director of Kew Gardens in 1865. The endemics he described were mainly collected by Tasmanian-based collectors whom he had recruited, in particular Ronald Gunn and Robert Lawrence (Burns \& Skemp 1961, Kantvilas 1996). However, Hooker spent nearly six months in Tasmania in 1840 and 1841 as part of his voyage to Antarctica. During this period, he specifically visited the central highlands to see the native habitat of the eucalypt from which Aborigines and stockmen collected and drank the often-fermented sap (Hooker 1845-1859, see also Potts et al. 2001). This species, known as the "Cider tree', and subsequently described by Hooker as $E$. gunnii, is now recognised as one of the most frost-resistant of all eucalypt species (Potts \& Potts 1986, Potts et al. 2001). At least in the Tasmanian context, this fact was evident early from Hooker's (1845-1859) description of the effects of the devastating frost of 1837 :

..." (which) had killed all the other and larger species of Eucalyptus, especially on flat grounds, similar to, but at a lower elevation than those on which we were. For

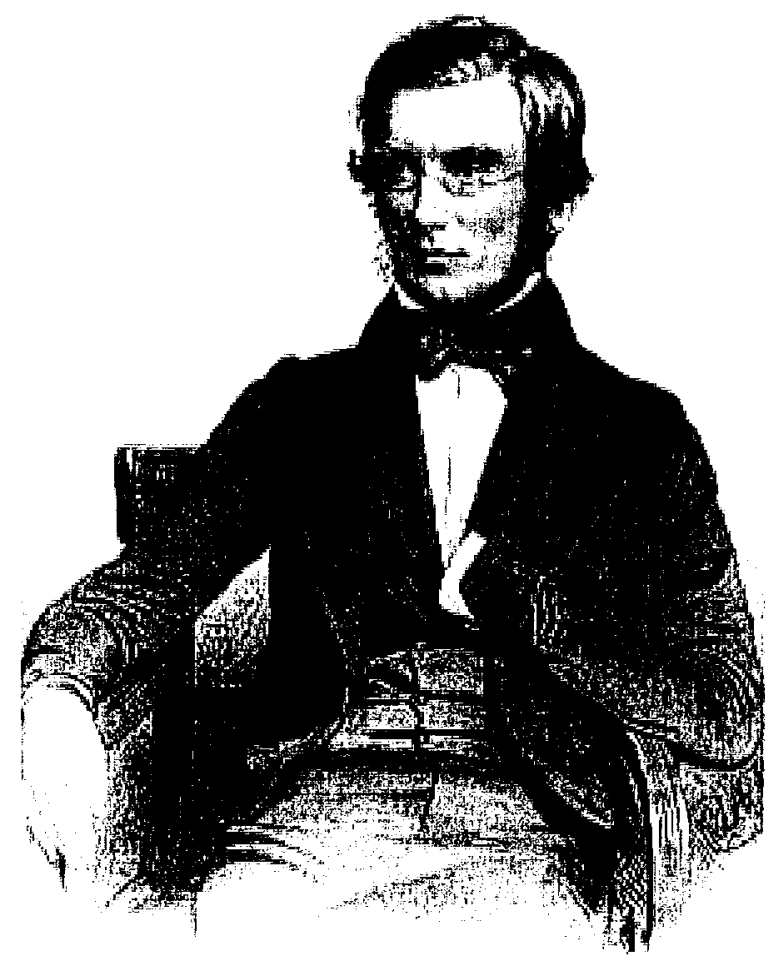

\section{PLATE 7}

The Kew-based botanist, Sir Joseph Dalton Hooker, who described five of the Tasmanian endemic eucalypts <http: //www.rbgkew.org.uk/aboutus/jhooker.htmls. (Reprinted with the permission of the Trustees of the Royal Botanic Gardens, Kew).

many miles on the road to the lakes, our course had been amongst the tall trunks of dead Gum trees... On the banks of Lake Echo, a beautiful sheet of water, a similar death-like scene met the eye. Gum trees, Leptosperma, Hakeas, and Banksias, all seemed as if they had been suddenly struck with some mortal disease in the full vigour of their growth, and in their prime of life.... the effects of the great frost of $1837, \ldots$ proves at once how much hardier this species ( $E$. gunnii) is, which, though growing at a much higher elevation, and on a marshy plain, where the effects of frost are always the most severe, was almost uninjured."

Because of its high frost resistance, extensive work has been undertaken on breeding E. gunnii in France (Potts \& Potts 1986, Cauvin et al. 1987) and this work has shown populations around Great Lake on the Central Plateau are the most frost-resistant of the species (Cauvin \& Potts 1987). The viability of these frost-resistant populations of E. gunnii on the Central Plateau are now threatened by extensive die-back which occurred in the 1990 s due to a combination of drought and browsing (Potts et al. 2001).

\section{TREES FROM THE ISLAND 1860-1937}

By the early twentieth century more than $80 \%$ of the Tasmanian eucalypt species had been formally described (see Kantvilas 1996), with most of the later species being 
described by mainland botanists working out of Melbourne (Mueller 1879-1884) or Sydney (Maiden 1903-1933; Barker \& Smith 1912) (Hall 1979). These species included E. regnans F. v. M, E. perriniana F. v. M ex Rodway, E. rubida Deane \& Maiden, E. delegatensis R.T. Baker, E. rodwayi Baker \& Smith, E. archeri Maiden \& Blakely, E. dalrympleana Maiden, E. jobnstonii Maiden and E. subcrenulata Maiden \& Blakely. Many of these species are non-endemicand were first described from mainland specimens. During this period botanists were still coming to terms with the exact constitution of the flora and the taxonomic priorities for naming (e.g., Rodway 1903, 1918, Maiden 1915, 1919, 1903-1933, Blakely 1934). For example, during this period $E$. pulchella was known as $E$. linearis Dehn., E. delegatensis as E. gigantea Hook. f., E. nitida Hook. f. as E. simmondsii Maiden, E. sieberi L.A.S. Johnson as $E$. sieberiana F. v. M., E. rodwayi as E. aggregata Deane \& Maiden., E. subcrenulata as E. muelleri T.B. Moore and $E$. amygdalina as E. salicifolia Cav. There were also taxa recorded in Tasmania described from hybrid material (e.g., from $\mathrm{Mt}$ Nelson, E. unialata Baker \& Smith $\{E$. viminalis $\mathrm{x} E$. globulus Maiden 1915\}; from Alma Tier, $E$. irbyi Baker \& Smith $\{E$. gunnii x E. dalrympleana Pryor \& Johnson 1971\}; and from St Marys Pass, E. taeniola Baker \& Smith $\{E$. amygdalina $\mathrm{x}$ E. sieberi Jackson 1958\}). In addition, there was incorrect assignment to mainland taxa that do not occur in Tasmania (e.g., E. haemastoma $\mathrm{Sm}$.) or incorrect affinities recorded to Tasmanian taxa (e.g., the Tasmanian E. perriniana F. v. M. had been described as $E$. gunnii Hook. f. var: glauca Deane \& Maiden). During this period, Baker \& Smith (1920) undertook a major survey of the essential oils of the genus Eucalyptus and those of the Tasmanian species, collected by L.G. Irby, were completed in 1912 (Barker \& Smith 1912). It was not until the 1990s that a similar task was repeated with modern analytical techniques (Li et al. 1995, 1996).

The early 1900 s saw the end of the pioneering stages of botanical discovery that focused on collecting, describing and classification. The next stage of discovery of the Tasmanian eucalypts moved to a more detailed and experimental approach to understanding the relationships between species and their evolution.

\section{TASMANIA'S INDEPENDENCE 1937}

The new era of scientific discovery was led by Tasmanian-based scientists. Its starting point can be traced to the presentation of three key papers at the annual meeting of the Royal Society of Tasmania on 8 November 1937. The first major study of eucalypt chromosomes and cell division was presented by McAulay \& Cruickshank (1938), expanding an earlier note in Nature (McAulay et al. 1936). This work was undertaken in the Physics Department at the University of Tasmania, where Alexander Leicester McAulay was the Professor. Hewas interested in the social and environmental applications of his discipline (Davis 1990) and had a great interest in the Tasmanian eucalypts. The chromosome studies required the most advanced optics available at the time and were undertaken with Fletcher Donaldson Cruickshank who was his second in charge and a specialist in optics. Interestingly, Cruickshank was a descendant of one of Tasmania's early explorers, Lieutenant John Hayes, who visited southern Tasmania two months after D'Entrecasteaux in 1793. Hayes' charting of this area and allocation of names such as Derwent River, Cornelian Bay, Risdon, Ralphs Bay (originally Relphs Bay) and Betsy Island, challenged the priority of the earlier French discoveries,

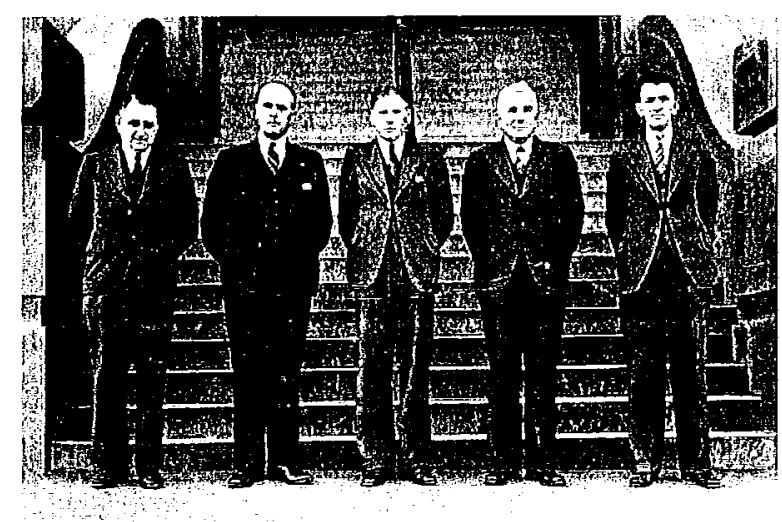

PLATE 8

Robert Gordon Lindsay Brett (far left) taken in 1939 outside the Hobart High School where he taught Science and Mathematics from 1918 to 1943 (from Batt 1963).

the reporting of which had been delayed by internment in Java as previously detailed (Lee 1912, Taylor 1973, Horner 1995). A cousin of Cruickshank's, Ernest Cruickshank, also played a key role in the Tasmanian Field Naturalists having E. globulus accepted as the floral emblem of Tasmania. The karyotype studies that McAulay and Cruickshank undertook heralded the University of Tasmania's long-running interest in eucalypt genetics that persists today, but in the School of Plant Science, not Physics.

At the same meeting, McAulay (1938) also presented a paper on the first experimental verification of natural hybridisation between two eucalypt species. Considerable debate had been held in scientific circles for decades as to whether eucalypt species hybridised in the wild (see Griffin et al. 1988). The first artificial hybrid had been produced by a nurseryman in Canberra (Maiden 1919) and Maiden had been arguing for some time that such hybrids did exist in the wild (Maiden 1904). However, it was McAulay who applied the genetic principles of progeny testing to give the first clear verification of their existence in the wild. The $E$. ovata $\mathrm{x}$ globulus hybrids he studied were found by Gordon Brett near Bagdad. Similar wild hybrids can be seen today at several sites on $\mathrm{Mt}$ Nelson and this hybrid combination has been produced artificially (Lopez et al. 2000).

The third key paper presented at this meeting was a major taxonomic review of the Tasmanian eucalypts by Gordon Brett (1938). This review was important as it challenged the concept of discrete biological species and recognised the large amount of variability and continuity within and between many of our described eucalypt species, a large part of which he believed to be due to hybridisation. Brett taught mathematics and science at Hobart High School (pl. 8) and had studied at the University of Tasmania under McAulay's father who was the Professor of Mathematics and Physics at the time. Brett went on to describe one of the rarest of all eucalypts, the Tasmanian endemic E. morrisbyi (Brett 1939). Brett almost completed another manuscript that was unfortunately lost to posterity in 1967, as in reflecting on Brett's life, Wilson (1975: 59) notes: "We recall the disastrous bush fires of 1967 when he lost his home, his professional library, most of his plants and other priceless treasures including the manuscript of his long awaited publication on eucalypts." 


\section{THE WAR EFFORT 1938-1950}

While off to a good start in the 1930s, there was little publication of eucalypt research during the decade of the Second World War. During this period, the optical skills of McAulay and Cruickshank, for example, were focused on military work and an optical annex was established at the University of Tasmania where staff supervised 280 workers producing camera and gun sight components designed by Cruickshank (Davis 1990). However, some of the earliest work on artificial hybridisation of eucalypts was undertaken in Tasmania during and immediately after the Second World War. For example, E. globulus x E. cordata crosses were performed and almost certainly involved an E. globulus female (St Davids Park) crossed with E. cordata from Summerleas Road. Gordon Brett was involved in this work and Max Gilbert (pers. com. 1984) indicated that the progeny were planted at Taranna in 1945 and that he assessed them in 1954. Crossing possibly started in 1940 and other plantings were made in 1949. Interestingly, Tasmania was not the only place where eucalypts were being artificially hybridised during this war period. The largest program of artificial hybridisation of eucalypts at the time was being undertaken in Russia at a research station located near the Black Sea (Pilipenka 1969), but full details of this research were only revealed following translation of a review in the late 1980s (Griffin et al. 1988).

\section{PATTERNS AND PROCESSES}

The postwar decade saw many of the lines of enquiry clearly established that are pursued today. These research lines aimed to understand the evolutionary processes that have led to the patterns of variation and species inter-relationships seen in Tasmania. This work was initiated by the foundation Professor of Botany (1947-1964), Horace Newton Barber (Barber 1963, pl. 9), and was continued by William (Bill) Dalziel Jackson (pl. 10) who was one of his Ph.D. students and later became Professor of Botany (1966-1986). Barber was trained in genetics and cytology at Cambridge and was a Fellow of the Royal Society of London whereas Jackson commenced university studies during the uptake of ex-service personnel following the Second World War and undertook all his studies at the University of Tasmania. They published in the highest quality journals a series of landmark papers on continuous (termed clinal) variation in the Tasmanian eucalypts (Barber $1955,1956,1965$, Barber \& Jackson 1957). This work was backed by their increasing knowledge of eucalypt biology (Barber 1954, Jackson 1958) and ecology (Jackson 1965, 1968 ), and clearly placed Tasmanian eucalypts on the modern scientific map (e.g., Jones \& Wilkins 1971, Endler 1977 \& 1986, Frankham et al. 2002).

\section{Natural Selection in Action}

A key paper was published in the journal Nature (Barber \& Jackson 1957) which described a steep cline in leaf glaucousness in E. urnigera on Mt Wellington, where at the lower altitudinal range the population is uniformly green while at the highest altitudes the population is uniformly glaucous due to a covering of extra-cuticular wax (fig. 1). This work was important, as Jackson (1960b) notes that at

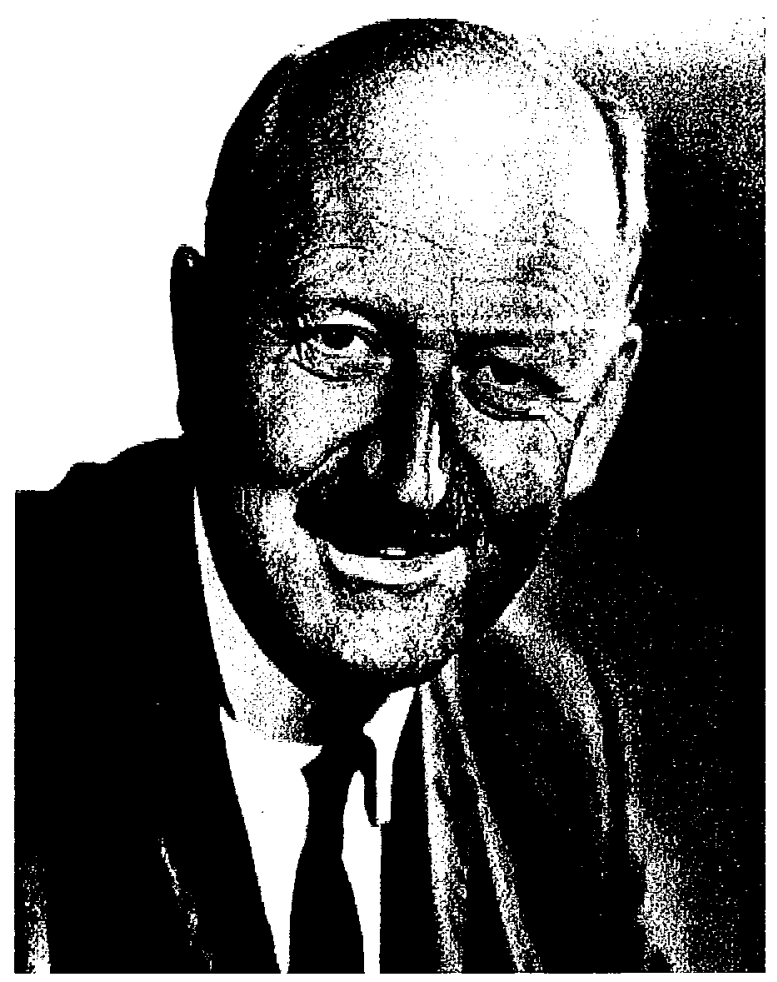

PLATE 9

H. Newton Barber, Professor of Botany at the University of Tasmania between 1947 and 1964, initiated early studies of the processes leading to the evolution of the Tasmanian eucalypt flora (photo from School of Plant Science).

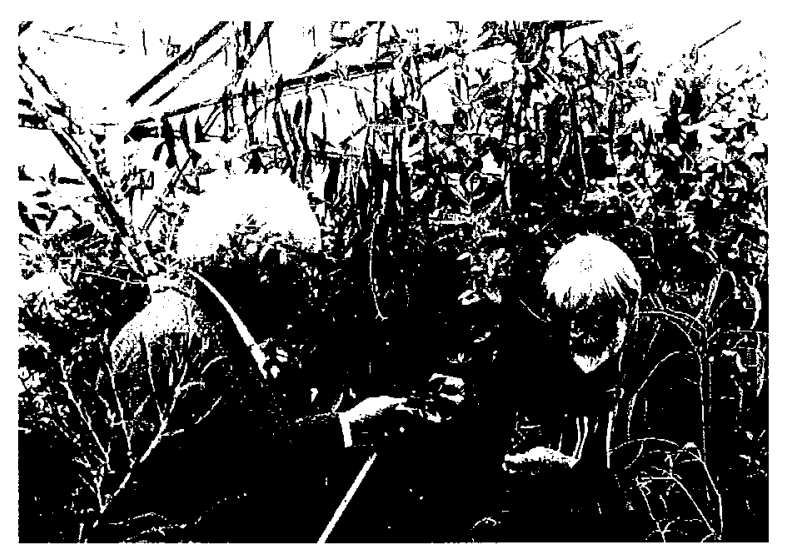

PLATE 10

Professor Bill Jackson (right) and Professor Lindsay D. Pryor in post-retirement discussion. There were two main research groups in Australia working on eucalypt genetics and evolution during the 1950s and early 1960s - one in Canberra with Pryor who was Professor of Botany at the Australian National University, the other in Tasmania where Professors Barber and Jackson were working. Professor Pryor focused on hybridisation during this period whereas the Tasmanian group was focusing on the role of natural selection in shaping variation patterns. 


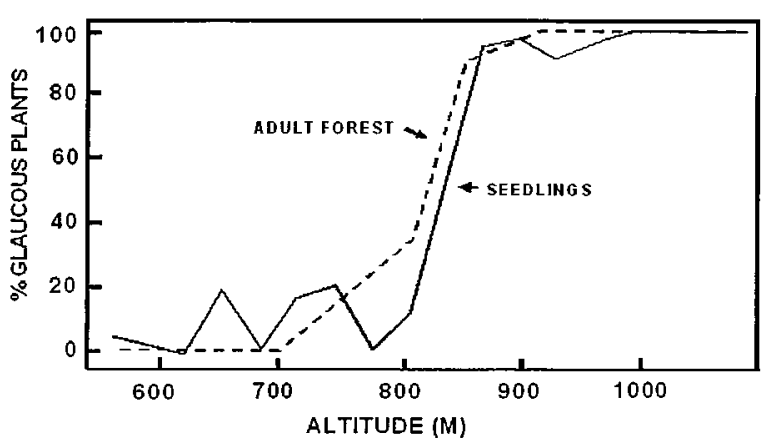

FIG. 1 - Clinal variation in the glaucousness of adult and juvenile foliage on Eucalyptus urnigera with altitude on $\mathrm{Mt}$ Wellington, Tasmania. The adult trees were scored in the native forest whereas the seedlings were grown in the nursery from open-pollinated seed collected from the wild (redrawn from Barber er Jackson 1957).

the time there was considerable controversy over the relative roles of genetic drift and natural selection in population differentiation (Wright 1948, Fisher \& Ford 1950), and even many selectionists concurred with Haldane's (1959) views that natural selection occurred slowly and acted in a centripetal manner to restrict variation and evolutionary pathways. Many thought evolution operated through subtle differences in fitness. However, Barber \& Jackson (1957) argued that there was nothing subtle about nature and that the changes in just one or two genes can mean the difference between life and death over very short geographical distances. Experimental evidence comparing phenotype frequencies in the adult and seedling cohorts supported the argument (Barber \& Jackson 1957) and a subsequent progeny trial at Collinsvale clearly indicated that glaucous individuals from high altitudes could not survive at low altitude sites (fig. 2). The functional differences in phenotype observed along this cline were later examined by Thomas $\&$ Barber (1974a, 1974b) in one of the earliest attempts to provide a mechanistic explanation for such clines and the variation in fitness. Subsequent research identified partial barriers to gene flow along this cline arising from a stepped cline in flowering time (Savva et al. 1988).

Barber and Jackson's ideas were strongly influenced by the concurrent work of Max Gilbert, from the Forestry Commission who was studying the regeneration of $E$. regnans forest in the Florentine Valley after fire (Gilbert 1959, Barber 1965). At a current maximum height of $92 \mathrm{~m}$ recorded on a tree in the nearby Styx Valley, this species is currently the world's tallest flowering plant in natural forest (Hickey et al. 2000) ${ }^{1}$. His work showed that fierce density dependent selection must occur as the regenerating forest thins from over 100000 seedlings per hectare after a fire to just a few per hectare ( 300 years post-fire), with only the very fittest surviving to contribute to the next generation. Intense selection against the products of inbreeding has subsequently been verified experimentally (Hardner \& Potts 1997).

\footnotetext{
${ }^{1}$ A recent laser-based measurement of a E. regnans tree in the Andromeda stand (the 'Mount' tree) has now given a tree height of $96 \mathrm{~m}$ (John Hickey pers. com. February 2003). The maximum height recorded for E. regnans in Tasmania is $99 \mathrm{~m}$ and for E. globulus $101 \mathrm{~m}$ (Hickey et al. 2000).
}
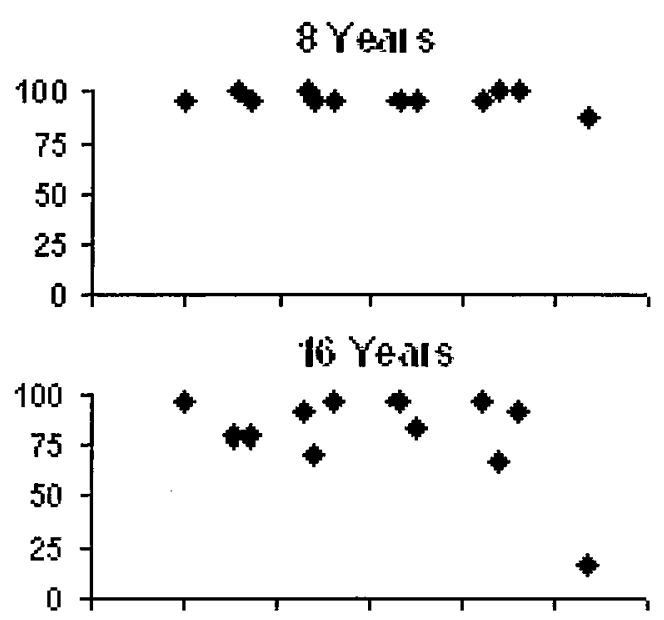

21 Yeals
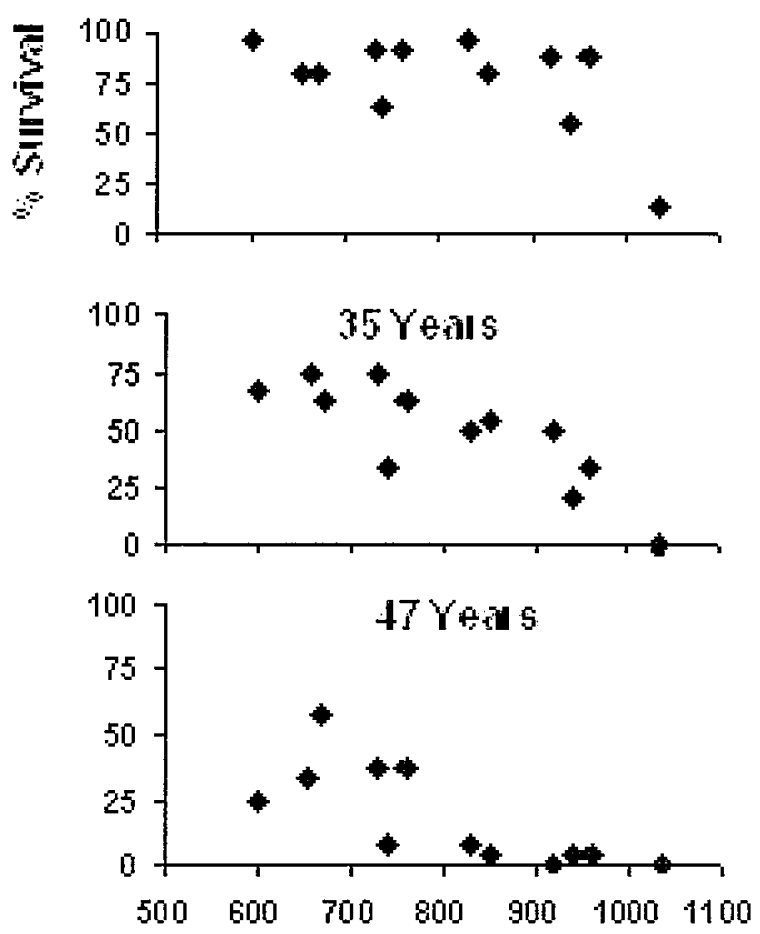

Altitule \{lin)

FIG. 2-Survival of open-pollinated progenies of Eucapytus urnigera collected at a range of altitudes on $M t$ Wellington in an experimental field trial at Collinsvale $(400 \mathrm{~m})$. The data (8-35 years old) were collected by students of Botany at the University of Tasmania and the 47-year-old data by $P$. Tilyard. While there is clear selection against the glaucous, high altitudinal forms compared with the green, low-altitude forms at this low altitude site, this selection was not manifest in differential survival until at least 16 years after planting. 

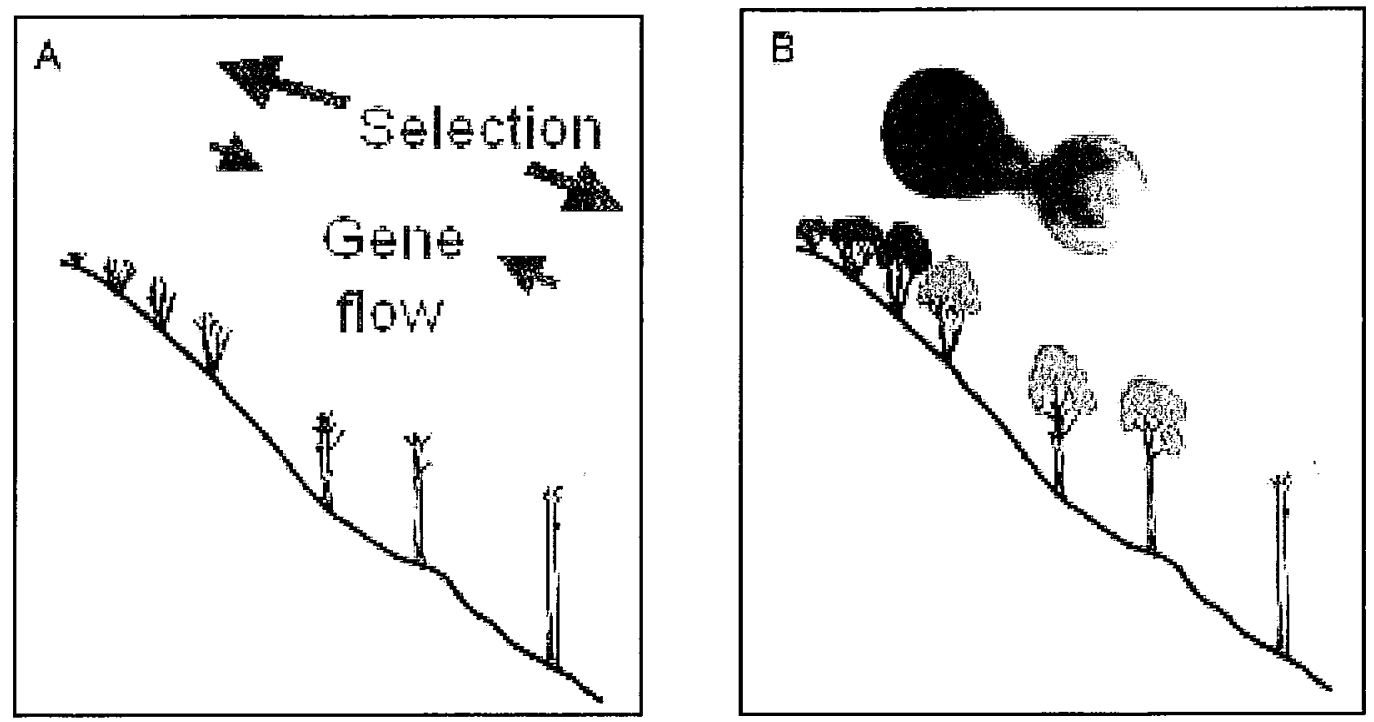

FIG. 3 - Hypotheses proposed to explain the origin of continuous variation in the Eucalyptus vernicosa complex on mountains in Tasmania include $(A)$ primary integration and $(B)$ secondary intergradation. Primary intergradation would involve disruptive selection acting initially on a single gene pool with differentiation of extremes occurring in situ and countered by gene flow. Secondary integration would involve extreme morphs differentiating in isolation followed by subsequent contact, then hybridisation and introgression creating a continuum (from McGowen 2000).

\section{Clinal Variation in the Tasmanian Yellow Gums}

Bill Jackson extended these studies of clinal variation from a single trait to the level of the whole plant phenotype in his Ph.D. studies on the TasmanianYellow gum complex (Jackson 1960a, 1960b). He showed that continuous variation exists between the three taxa from the unique shrub-like eucalypt $E$. vernicosa on mountain-tops, through $E$. subcrenulata to the tall trees with affinities to $E$. johnstonii in the sub-alpine forests. He attempted to deal with these multivariate clines but was hampered by the lack of computing power, instead being forced to use bivariate plots and ratios to display the multivariate phenotypic patterns. The genetic basis of these clines was demonstrated unequivocally through the development of common experimental gardens for seedlings derived from seed collected from different parts of the altitudinal range (pls 11-13).

The key question Bill Jackson was attempting to answer was how do these highly differentiated clines arise? He postulated two mechanisms (Jackson 1960b) to explain their origin:

(i) intense disruptive selection acting on asingle population (fig. 3A), or

(ii) hybridisation between forms that have evolved in geographic isolation and subsequently come into contact (fig. 3B).

A major component of his work involved establishing a rigorous statistical approach to the quantification of this variation. In this respect he was strongly influenced by Sir Ronald Fisher $(1930,1936,1937)$ who was the father of modern statistics and was based at the University of Adelaide during the late 1950s and interacted with the research group at the University of Tasmania during this period. This era founded Bill Jackson's long-standing interest in the application of statistics to biological problems and many students have fond memories of his long-running
Biometry course.

\section{QUANTITATIVE GENETICS}

The line of statistical research established by Bill Jackson has led to the School of Plant Science at the University of Tasmania now having one of the largest research groups studying quantitative genetics of eucalypts. This work aims to use the phenotypic similarity between relatives in experimentallydesigned trials of either open-pollinated or full-sib (known mother and father) progenies to estimate the extent to which traits are under genetic control. The application of this work to tree breeding involves using such experiments to predict which parents or offspring carry the most favourable genes or gene combinations. The scale of the experiments currently being undertaken and the technology for their analysis would be beyond the imagination of scientists of the 1960 s and even 1970s. Many of the statistical and multivariate analyses that Bill Jackson was attempting were innovative and beyond the technology of the time. Calculations that were then taking months to do are now standard and can be done in seconds using high-speed computers.

Quantitative genetic studies of population variation in many of the Tasmanian eucalypt species have now been undertaken by students and staff at the University of Tasmania. Species studied include E. dalrympleana and E. viminalis (Phillips \& Reid 1980), E. coccifera and $E$. nitens (Shaw et al. 1984), E. gunnii and E. archeri (Potts \& Reid 1985a, 1985b), E. perriniana (Wiltshire \& Reid 1987), E. cordata (Potts 1989), E. risdonii and E. tenuiramis (Wiltshire et al. 1991, 1992, 1998, Turner et al. 2001), and E. barberi (McEntee et al. 1994). However, it is the quantitative genetic work on E. globulus that has made this species one of the most intensively-studied forest tree species (reviewed in Dutkowski \& Potts 1999, Raymond 2001, Lopez et al. 2002). Professor Jamie Kirkpatrick 

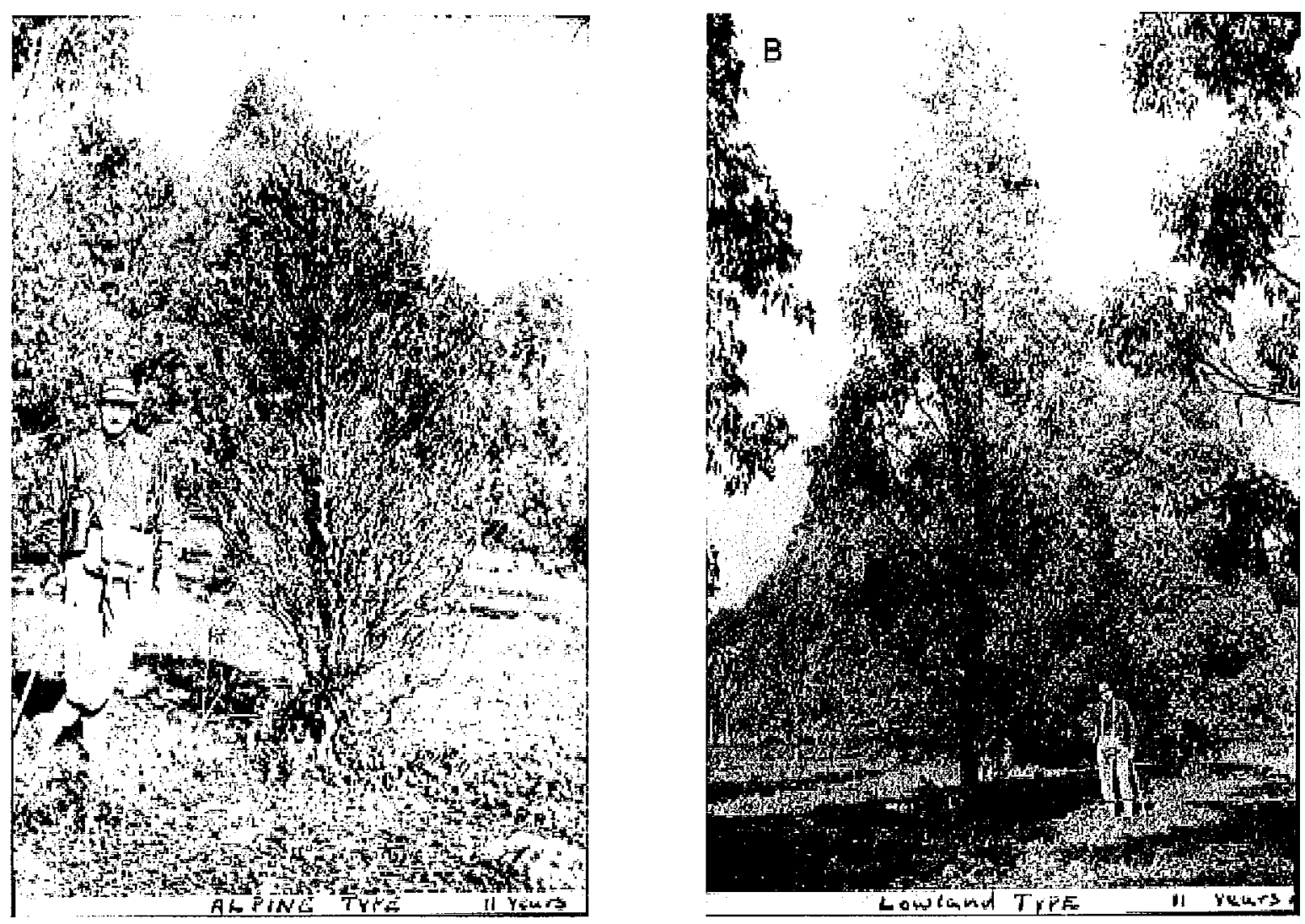

PLATE 11

Eleven-year-old plants of $(A)$ an alpine type intermediate between Eucalyptus subcrenulata and $\mathrm{E}$. vernicosa and $(B)$ a forest type E. johnstonii at an arboretum at Stoodley in northern Tasmania (240 m altitude) (from Jackson 1960b).

PLATE 12

Typical five-year-old seedling of Eucalyptus vernicosa (leftFranklin Range $760 \mathrm{~m}$ ), E. subcrenulata (right-Frankland Range $550 \mathrm{~m}$ ) and E. johnstonii (Mt Wellington $730 \mathrm{~m}$ ) grown in a common environment at Hobart demonstrate a genetic basis to variation in plant growth and form (from Jackson 19606).
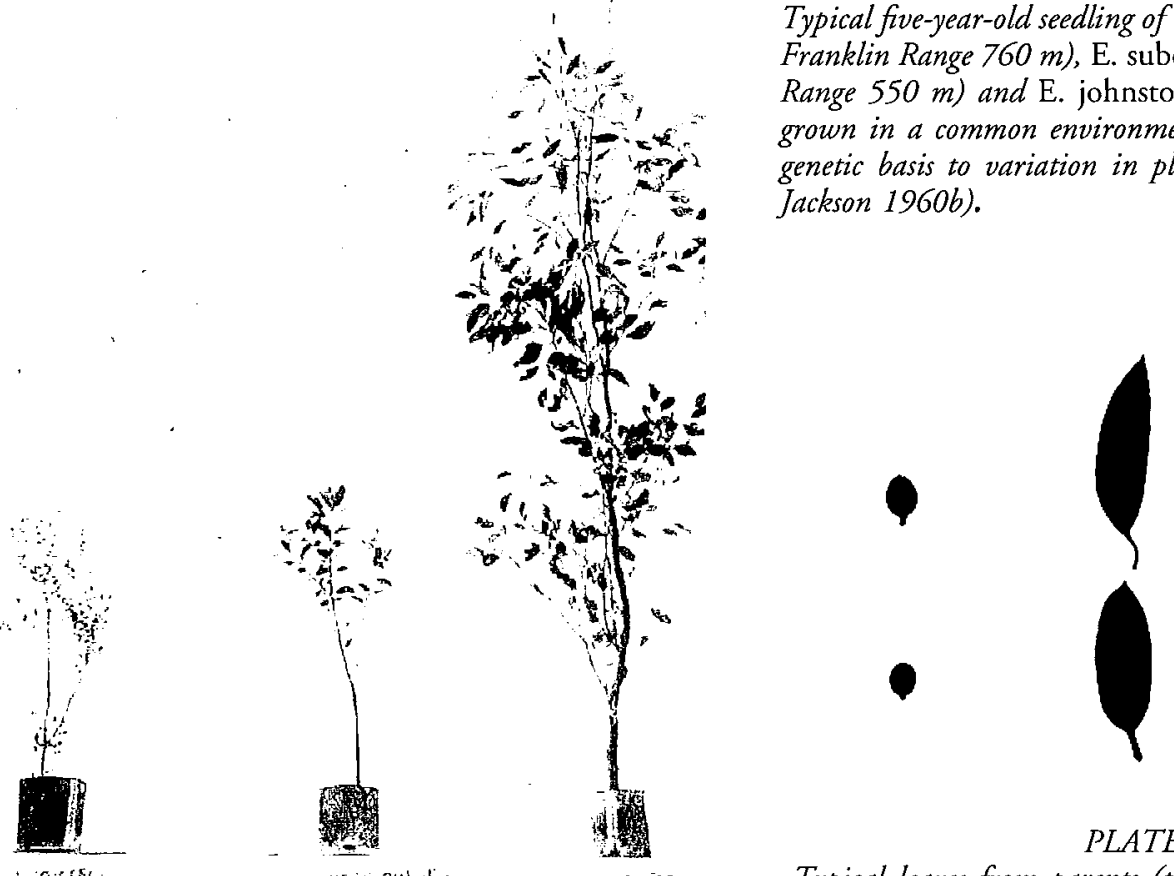

PLATE 13

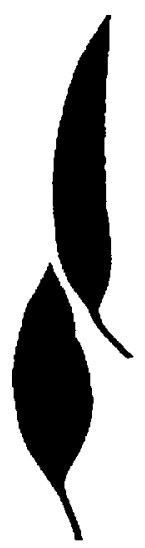

Typical leaves from parents (top) and progeny raised in a common environment at Hobart (bottom) showing a strong genetic basis to variation in leaf morphology between Eucalyptus vernicosa, E. subcrenulata and E. johnstonii forms in Plate 12 (from Jackson 19606). 


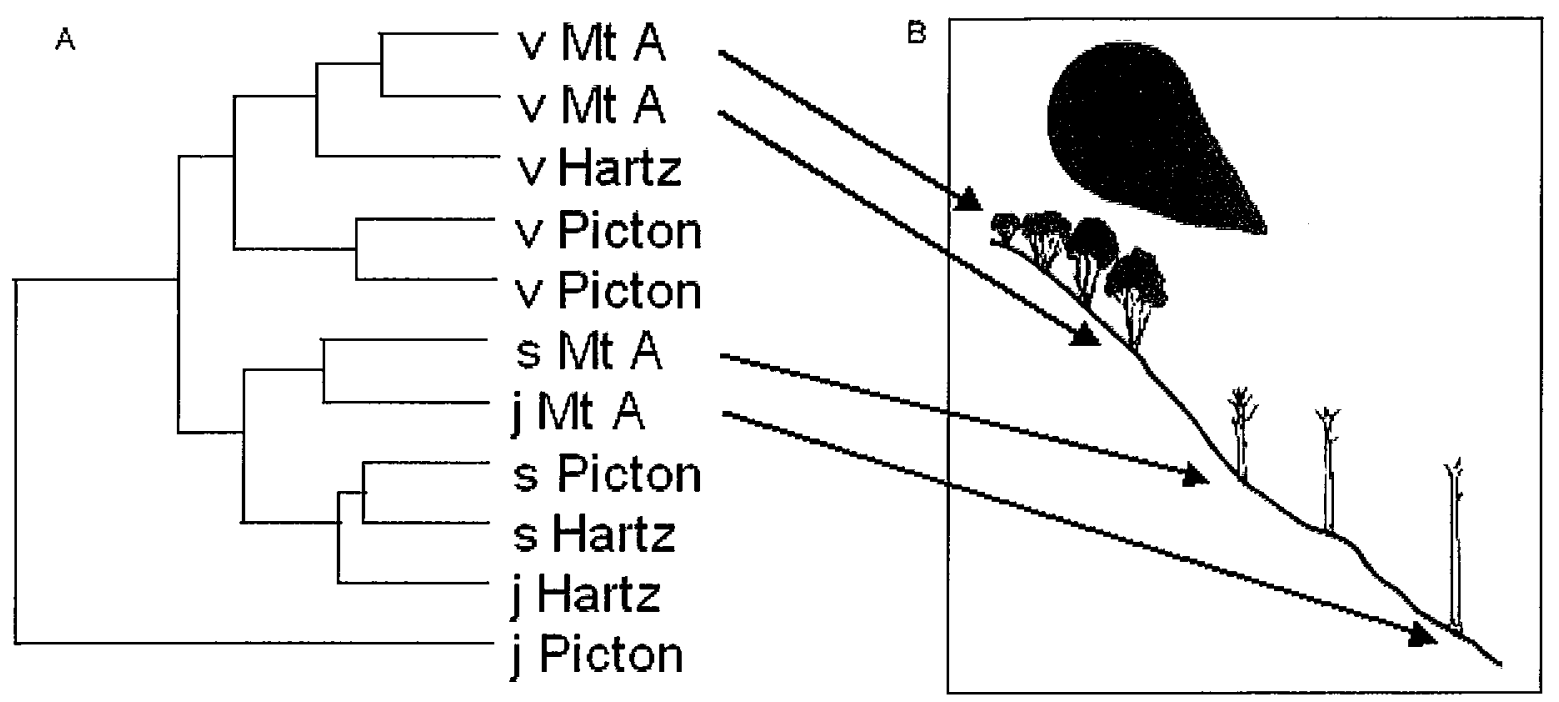

FIG. 4.- A dendogram showing molecular affinities of populations of the Eucalyptus vernicosa complex (A) based on microsatellite markers which are believed to be neutral to selection (from McGowen et al. 2001). Plants with affinities to $\mathrm{E}$. vernicosa (v), E. subcrenulata (s) and E. johnstonii (j) trees were sampled along altitudinal gradients at three locations (Mt Arrowsmith, Mt Picton and the Hartz Mountains). The hypothesis explaining the origin of the continutum between E. vernicosa and tall forest forms resembling $\mathrm{E}$. johnstonii in habit at the base of the mountain is shown in (B) (from McGowen 2000). In this case it is argued that in contrast to previous suggestions (fg. 3), the continuum is due to the convergence of two gene pools towards the same morph at intermediate altitudes (McGowen et al. 2001).

undertook the first major study of E. globulus during his Ph.D. studies at the University of Melbourne (Kirkpatrick 1975, see also Jordan et al. 1993). The patterns of diversity in the E. globulus gene pool have now been studied in large, range-wide collections of open-pollinated seed lots that have been distributed around the world for breeding purposes, starting over 25 years ago (Orme 1977, Borralho et al. 1992, Eldridge et al. 1993, Lopez et al. 2001). We now know the extent of genetic control of numerous traits including those affecting growth and survival, tree form, sexual reproduction, the timing of the distinctive heteroblastic change, characteristics of the juvenile leaf, coppicing and lignotuber development, bark and wood properties, and susceptibility to numerous pests. We know how genetic variation in the various traits is correlated, and how the expression of this variation changes with age and environment. We know how this genetic variation is distributed in native populations, not only on a broad geographic scale (Dutkowski \& Potts 1999), but also within (Hardner et al. 1998) and between (Jordan et al. 2000) local populations. This detailed genetic knowledge is superimposed on a detailed understanding of breeding systems (e.g., Patterson et al. 2001, Pound et al. 2002), pollination ecology (Hingston 2002) and hybridisation potential (Gore et al. 1990, Potts et al. 2000, Volker 2002), Such knowledge, coupled with simple techniques now developed for controlled pollination (Williams et al. 1999), has made E. globulus a model tree species for genetic and evolutionary studies.

\section{MOLECULAR GENETICS 1990 ONWARDS}

A new era in our understanding of eucalypt genetics and evolution has come about through the revolution in molecular genetic technologies that has occurred over the past decade. Researchers in the School of Plant Science were the first to publish on DNA variation in eucalypts (Steane et al. 1991, Sale et al. 1993), and the stimulus for this work was the development of tools to study the evolution of the Tasmanian eucalypts. We can now monitor directly variation not only in the nuclear DNA (e.g., Steane et al. 2001, 2002), but also in the small maternally inherited DNA molecules in the chloroplast (Vaillancourt \& Jackson 2000, McKinnon et al. 2001b) and mitochondria (R. E. Vaillancourt \& A. Petty, unpubl. data) of eucalypt cells.

The development of this DNA technology has taken many years, but we are now at the stage where it can be applied on a large scale to address some of the questions Bill Jackson was asking decades ago. We have studied his Yellow gum cline and to our surprise the molecular data suggest that the continuum he observed is actually the result of the convergence of two separate gene pools (McGowen et al. 2001: fig. 4). DNA markers have revealed marked differentiation between populations of E. globulus (Nesbitt et al. 1995) with mainland populations morphologically classifying as the Tasmanian Blue gum, quite different from Tasmanian populations (Jones et al. 2002). Studies of the patterns of chloroplast variation in E. globulus and other Tasmanian species have provided evidence for past migration routes and glacial forest refugia (Freeman et al. 2001) and the sharing of the same chloroplast types by many species has provided evidence for ancient hybridisation amongst our species on a previously unimaginable scale (Steane $e t$ al. 1998, McKinnon et al. 1999, 2001a, in press).

\section{THE FUTURE}

The next decade will see major advances in our understanding of the eucalypt genome, due to research that is mainly driven by the worldwide commercial significance of eucalypts. The Tasmanian species have and will continue to play an important 
role in this research. The first sequence of the important lignin gene CAD in trees was undertaken by French researchers working at the University of Toulouse with the Tasmanian endemic, E. gunnii (Feuillet et al. 1993, Grima Pettenati et al. 1993). This was also the first eucalypt-specific gene sequence published. Rudimentary maps of the genome of several eucalypt species have now been published. E. globulus is one of the species most intensively studied and maps of its genome have been published by Australian (Vaillancourt $e t$ al. 1994, Bundock et al. 2000, Thamarus et al. 2002) and overseas (Marques et al. 1998) research groups. Research is now focusing on identifying mutations, genes or genomic regions responsible for the variation in traits of economic significance including growth, propagation and wood quality traits (Marques et al. 1999, Moran et al. 2002, Thamarus et al. 2002, Poke et al. 2003) as well as hybrid inviability (Vaillancourt et al. 1994, Myburg et al. 2003). There are now several databases containing the sequences of many of the genes expressed in various tissues (e.g., cambium) of Eucalyptus, but these are not publicly available and are small compared to those available in crop species. Moves are already afoot to increase such sequencing efforts overseas (e.g., the GENOLYPTUS project in Brazil; Grattapaglia 2001) and there is growing interest in commencing large-scale sequencing of the eucalypt genome - just as has been done with the human genome.

While such genome studies with eucalypts can and are being done in many laboratories around the world, researchers at the University of Tasmania have a special niche. In addition to the technology, there is ready access to the natural ecosystem on an island with great diversity in environments and plant adaptation in which to apply these techniques. This is coupled with a long history of scientific exploration of eucalypt genetic diversity as well as clearly defined questions to answer thanks to the efforts of visionary botanists such as Newton Barber and Bill Jackson.

\section{ACKNOWLEDGEMENTS}

We thank Paul Tilyard, Rachel Lawrence, Peter Gore and the State Library of Tasmania for their assistance in the preparation of this manuscript. We also thank Marian Lorkin and Robert Wiltshire for permission to reproduce figures 3 and 4, Edward Duyker for permission to reproduce plate 1 , Wendy Potts and René Vaillancourt for their comments on the manuscript, and Patrick Dalton for encouraging its preparation.

\section{REFERENCES}

BaKer, R. T. \& Simith, H. G., 1912: A research on the eucalypts of Tasmania and their essential oils. Papers and Proceedings of the Royal Society of Tasmania: 139-209.

BAKER, R. T. \& SMiTH, H. G., 1920: $A$ research on the eucalypts especially in regard to their essential oils. Sydney Government Printer, Sydney: 471 pp

Barber, H. N., 1954: A sterile eucalypt. Papers and Proceedings of the Royal Society of Tasmania 88: 285-287.

BARBER, H. N., 1955: Adaptive gene substitutions in Tasmanian eucalypts: I. Genes controlling the development of glaucousness. Evolution 9: 1-15.

BARBER, H. N., 1956: The natural history of natural selection. The Australian Journal of Science: 148-159.
BARBER, H. N., 1963: Botanist's Miscellany. Reproduced privately by N.H. Rebrab, Printer under the Sign of the Dr. Syntax, Sandy Bay Rd., Hobart. 162 pp.

BARber, H. N., 1965: Selection in natural populations. Heredity 20: 551-572.

BARber, H. N. \& JACKSON, W. D., 1957: Natural selection in action in Eucalyptus. Nature 179: 1267-1269.

BATT, N., 1963: Fifty years, 1913-1963: the history of the Hobart High School. The School, Hobart. 96 pp.

Blakely, W. F., 1934: A Key to the Eucalypts. The Worker Trustees, Sydney: 339 pp.

Borralho, N. M. G., Cotterill, P. P. \& Kanowski, P. J., 1992: Genetic parameters and gains expected from selection for dry weight in Eucalyptus globulus ssp. globulus in Portugal. Forest Science 38: 80-94.

BRETT, R. G., 1938: A survey of the Eucalyptus species in Tasmania. Papers and Proceedings of the Royal Society of Tasmania 71: 75-109.

BRETT, R. G., 1939: The description of a new eucalypt species. Papers and Proceedings of the Royal Society of Tasmania (1937): 129-130.

BRooker, M. I. H., 2000: A new classification of the genus $\mathrm{Eu}$ calyptus L'Hér. (Myrtaceae). Australian Systematic Botany 13: 79-148.

Brooker, M. I. H. \& KueinIG, D. A., 1990: Field guide to Eucalypts. Volume 2. South-western and southern Australia. Inkata Press, Sydney: $428 \mathrm{pp}$.

Bundock, P. C., Hayden, M. \& Valllancourt, R. E., 2000: Linkage maps of Eucalyptus globulus using RAPD and microsatellite markers. Silvae Genetica 49: 223-232.

Burns, T. E. \& SKEMP, R. J., 1961: Van Dieman's Land Correspondents. Records of the Queen Victoria Museum 14: $1-142$.

Cauvin, B. \& PotTs, B.M., 1991: Selection for extreme frost resistance in Eucalyptus. In Schönau, A.P.G. (Ed.): Intensive Forestry: The Role of Eucalypts. Proceedings of the IUFRP symposium, P2.02-01. Productivity of Eucalypts, 2-6 September 1991, Durban South Africa. Southern African Institute of Forestry, Durban: 209-220.

Cauvin, B., Potts, B.M. \& Potts, W.C., 1987: Eucalyptus: hybridation artificielle - barrieres et hérédité des caracteres. Annales de recherches sylvicoles (Association Forêt-Cellulose: Paris) 1987: 255-303.

Curtis, W. M. \& Somerville, J., 1948: Boomer Marsh - a preliminary botanical historical survey. Proceedings of the Royal Society of Tasmania 1947: 151-157.

DAVIS, R., 1990: Open to talent: The centenary history of The University of Tasmania 1890-1990. University of Tasmania, Hobart: 256 pp.

DE BEER, G., 1960: The sciences were never at war. Nelson, London: 279 pp.

DougHTY, R. W., 2000: The Eucalyptus. A natural and commercial history of the gum tree. The Johns Hopkins University Press, Baltimore and London: 237 pp.

DutkowskI, G. W. \& PotTs, B. M., 1999: Geographical patterns of genetic variation in Eucalyptus globulus ssp. globulus and a revised racial classification. Australian Journal of Botany 46: 237-263.

DUYKER, E., 1992: The discovery of Tasmania: Joumal extracts from the expeditions of Abel Janszoon Tasman and Marc-Joseph Marion Dufresnen 1642 \& 1772 . St David's Park Publishing, Hobart: $106 \mathrm{pp}$.

DUYKER, E., 2003: Citizen Labillardiére : a naturalist's life in revolution and exploration (1755-1834). Miegunyah Press, Carlton: 383 pp. 
Duyker, E. \& Duyker, M., 2001: Voyage to Australia and the Pacific 1791-1793. Melbourne University Press, Melbourne. $392 \mathrm{pp}$

Eldridge, K., Davidson, J., Harwood, C. \& Van Wy, G., 1993: Eucalypt domestication and breeding. Clarendon Press, Oxford: $288 \mathrm{pp}$.

ENDLER, J. A., 1977: Geographical variation, speciation and clines. Princeton University Press, Princeton: 246 pp.

EndleR, J. A., 1986: Natural selection in the wild. Princeton University Press, Princeton: 336 pp.

Feuillet, C., Boudet, A. M. \& Grima Pettenati, J., 1993: Nucleotide sequence of a cDNA encoding cinnamyl alcohol dehydrogenase from Eucalyptus. Plant Physiology 103: 1447.

FISHER, R. A., 1930: The genetic theory of natural selection. Oxford University Press, Oxford: $272 \mathrm{pp}$.

FISHER, R. A., 1936: The measurement of selection intensity. Proceedings of the Royal Society of London, Series B 121: 58-62.

FISHER, R. A., 1937: The relationship between variability and abundance shown by the measurement of the eggs of British-nesting birds abundance. Proceedings of the Royal Society of London, Series B 122: 1-26.

Fisher, R. A. \& FORD, E. B., 1950: The "Sewall Wright effect". Heredity 4: 117-119.

Freeman, J. S., Jackson, H. D., Steane, D. A., Mckinnon, G. E., Dutkowski, G. W., PotTs, B. M. \& VallLancourt, R. E., 2001: Chloroplast DNA phylogeography of Eucalyptus globulus. Australian Journal of Botany 49: 831-835.

Frankham, R., Ballou, J. D. \& Briscoe, D. A., 2002: Introduction to Conservation Genetics. Cambridge University Press, Cambridge.

GiLBerT, J. M., 1959: Forest succession in the Florentine Valley, Tasmania. Papers and Proceedings of the Royal Society of Tasmania 93: 129-151.

Gore, P. L., PotTs, B. M., Volker, P. W. \& Megalos, J., 1990: Unilateral cross-incompatibility in Eucalyptus: the case of hybridisation between $E$. globulus and E. nitens. Australian Journal of Botany 38: 383-394.

Grattapaglia, D., 2001: Genomic technologies for the development of the eucalypt of the future. In Developing the Eucalypt of the Future, Proceedings of IUFRO International Symposium, 10-15th September 2001. Valdivia, Chile.

Griffin, A. R., Burgess, I. P. \& Wolf, L., 1988: Patterns of natural and manipulated hybridisation in the genus Eucalyptus L'Hérit. - a review. Australian Journal of Botany 36: 41-66.

Grima Pettenati, J., Feulllet, C., Goffner, D., Borderies, G. \& BoudeT, A. M., 1993: Molecular cloning and expression of a Eucalyptus gunnii cDNA clone encoding cinnamyl alcohol dehydrogenase. Plant Molecular Biology 21: 1085-1095.

Haldane, J. B. S., 1959: The theory of natural selection today. Nature 183: 710-713.

HaLL, N., 1979: Botanists of the etcalypts. CSIRO, Melbourne: $160 \mathrm{pp}$.

Hardner, C. M. \& PotTs, B. M., 1997: Post-dispersal selection under mixed-mating in Eucalyptus regnans. Evolution 51: 103-111.

Hardner, C. M., PotTs, B. M. \& Gore, P. L., 1998: The relationship between cross success and spatial proximity of Eucalyptus globulus ssp. globulus parents. Evolution 52: 614-618.

HAY, A., 2002: Gum - The story of eucalypts and their champions. Duffy \& Snellgrove, Sydney: 275 pp.
Hickey, J. E., Kostoglou, P. \& SARgison, G. J., 2000: Tasmania's tallest trees. Tasforests 12: 105-105.

Hingston, A. B., 2002: Pollination Ecology of Eucalyptus globulus Labill. ssp. globulus and E. nitens (Deane \& Maiden) Maiden (Myrtaceae). Unpublished PhD thesis. University of Tasmania, Hobart.

HOOKER, J. D., 1845-1859: Botany of the Antarctic Voyage of H.M. Discovery Ships Erebus and Terror in the years 1939-1843. Reeve, London. 3 vols, 6 parts.

Horner, F., 1995: Looking for La Pérouse. Melbourne University Press, Melbourne: $318 \mathrm{pp}$.

IRbY, L. G., 1925: The Tasmanian forests. Australian Forestry Journal 8: 234-236.

JACKSON, W. D., 1958: Natural hybrids in eucalypts. Part I. E. X taeniola ( $=$ E. salicifolia $\times$ E. sieberiana). Papers and Proceedings of the Royal Society of Tasmania 92: 141-146.

JACKSON, W. D., 1960a: Clinal variation in Eucalyptus vernicosa, Part I. Taxonomic treatment. Unpublished PhD thesis, University of Tasmania.

JACKSON, W. D., 1960b: Clinal variation in Eucalyptus vernicosa, Part II. The origin of clinal variation. Unpublished manuscript, University of Tasmania.

JACKSON, W. D., 1965: The Vegetation. In Davies, J. L. (Ed.): Atlas of Tasmania. Government Printer, Hobart: 30-35.

JACKSON, W. D., 1968: Fire, air, water and earth - an elemental ecology of Tasmania. Proceedings of the Ecological Society of Australia 3: 9-16.

JACOBS, M. R., 1981: Eucalypts for Planting. FAO, Rome:677 pp.

JONES, D. A. \& WILKINS, D. A. R., 1971: Variation and adaptation in plant species. Heinemann Educational, London: $184 \mathrm{Pp}$.

Jones, R. C., Steane, D. A., Potts, B. M. \& Vaillancourt, R. E., 2002: Microsatellite and morphological analysis of Eucalyptus globulus populations. Canadian Journal of Forest Research 32: 59-66.

Jordan, G. J., Potts, B. M., Chalmers, P. \& Wiltshire, R. J. E., 2000: Quantitative genetic evidence that the timing of vegetative phase change in Eucalyptus globulus ssp globulus is an adaptive trait. Australian Journal of Botany 48: 561-567.

Jordan, G. J., Potts, B. M., Kirkpatrick, J. B. \& Gardiner, C., 1993: Variation in the Eucalyptus globulus complex revisited. Australian Journal of Botany 41: 763-785.

KaNTVILAS, G., 1996: The discovery of Tasmanian eucalypts: an historical sketch. Tasforests 8: 1-14.

KirkPatRICK, J. B., 1975: Geographical Variation in Eucalyptus globulus. Australian Government Publishing Service, Canberra: $64 \mathrm{pp}$.

Kostoglou, P., 1994a: Historic timber-getting between Cockle Creek and Lune River Block 1. Archaeology of the Tasmanian Timber Industry Report No. 4. Tasmanian Forest Research Council, Inc, Hobart: 200 pp.

Kostoglou, P., 1994b: Historic timber-getting between Hastings and Dover Block 2. Archaeology of the Tasmanian Timber Industry Report No. 5. Tasmanian Forest Research Council, Inc, Hobart: 190 pp.

Kostoglou, P., 1995: Historic timber-getting on Bruny Island. Archaeology of the Tasmanian Timber Industry Report No. 7. Tasmanian Forest Research Council, Inc, Hobart: $108 \mathrm{pp}$.

Labillardière, J. J. D., 1800: Relation du Voyage à la Recherche de la Pérouse. H.J. Jansen, Paris. 2 vols and atlas.

Labillardière, J. J. D., 1804-07: Novae Hollandiae Plantarum Specimen. Dominae Huzard, Paris. 2 vols. 
LADIGES, P. Y., 1997: Phylogenetic history and classification of eucalypts. In Williams J. \& Woinarski J. (Eds): Eucalypt Ecology: Individuals to Ecosystems. Cambridge University Press, Cambridge.

Ladiges, P. Y. \& Udovicic, F., 2000: Comment on a new classification of the eucalypts. Australian Systematic Botany 13: $149-152$.

LEE, I., 1912: Commodore Sir John Hayes, his voyage and life. Longman, Green and Co., London: 340 pp.

LEWIN, D. W., 1905: The Eucalypti hardwood timbers of Tasmania. Gray Brothers, Hobart: $30 \mathrm{pp}$.

LEWIN, D. W., 1906: The Eucalypti hardwood timbers of Tasmania ( $2^{\text {nd }}$ edition). Gray Brothers, Hobart: $138 \mathrm{pp}$.

L'Hérttier De Brutelle, C. L., 1788: Sertum Anglicum. Facsimile edition 1963. Hunt Botanical Library, Pittsburg.

Li, H., Madden, J. L. \& PotTs, B. M., 1995: Variation in volatile leaf oils of the Tasmanian Eucalyptus species. 1. Subgenus Monocalyptus. Biochemical Systematics and Ecology 23: 299-318.

Li, H., Madden, J. L. \& Potrs, B. M., 1996: Variation in volatile leaf oils of the Tasmanian Eucalyptus species. II. Subgenus Symphyomyrtus. Biochemical Systematics and Ecology 24: 547-569.

Lopez, G., PotTs, B., DutKowski, G., Apiolaza, L. \& Gelid, P., 2002: Genetic variation and inter-trait correlations in Eucalyptus globulus base population trials in Argentina. Forest Genetics 9: 223-237.

Lopez, G. A., Potts, B. M., DutKowski, G. W. \& Rodriguez Traverso, J. M., 2001: Quantitative genetic of Eucalyptus globulus: Affinities of land race and native stand localities. Silvae Genetica 50: 244-252.

Lopez, G. A., PotTs, B. M. \& Tilyard, P. A., 2000: F hybrid inviability in Eucalyptus: the case of E. ovata $\times$ E. globulus. Heredity 85: 242-250.

Maiden, J. H., 1903-1933: A critical revision of the genus Eucalyptus. Government Printer, Sydney. 8 vols.

Maiden, J. H., 1904: On hybridization in the genus Eucalyptus. Australian Association for the Advancement of Science 1904: 297-303.

Maiden, J. H., 1915: Notes on Tasmanian eucalypts. Papers and Proceedings of the Royal Society of Tasmania 1914: $20-31$.

Maiden, J. H., 1919: Notes on Tasmanian eucalypts. Papers and Proceedings of the Royal Society of Tasmania 1918: 82-90.

Marques, C. M., Araujo, J. A., Ferreira, J. G., Whetten, R., OMalley, D. M., liu, B. H. \& Sederofe, R., 1998: AFLP genetic maps of Eucalyptus globulus and E. tereticornis. Theoretical and Applied Genetics 96: 727-737.

Marques, C. M., Vasquez-Kool, J., Carocha, V. J., Ferreira, J. G., OMalley, D. M., Liu, B. H. \& Sederoff, R., 1999: Genetic dissection of vegetative propagation traits in Eucalyptus tereticornis and E. globulus. Theoretical and Applied Genetics 99: 936-946.

Mcaulay, A. L., Cruickshank, F. D. \& Brett, R. G., 1936: Chromosome number of Eucalyptus globulus and Eucalyptus johnstoni. Nature 138: 550.

MCAULAY, A. L., 1938: Evidence for the existence of a natural hybrid between Eucalyptus globulus and Eucalyptus ovata. Papers and Proceedings of the Royal Society of Tasmania 1937: 45-46.

McAulay, A. L., Cruickshank F. D., 1938: The male meiotic cycle in the genus Eucalyptus. Papers and Proceedings of the Royal Society of Tasmania 1937: 41-44.

McEntee, A. C., Potts, B. M. \& Reid, J. B., 1994: Variation in Eucalyptus barberi L. Johnson \& Blaxell. Papers and Proceedings of the Royal Society of Tasmania 128: 21-30.

McGowen, M. H., 2000: Clinal variation in the Yellow Gum complex. unpublished BSc (Hons) thesis. School of Plant Science, University of Tasmania.

MCGowen, M. H., Wiltshire, R. J. E., PotTs, B. M. \& VAilLANCOURT, R. E., 2001: The origin of Eucalyptus vernicosa, a unique shrub eucalypt. Proceedings of the Royal Society of London 74: 397-405.

MCINTYRe, K. G., 1977: The secret discovery of Australia. Souvenir Press Ltd, London. 427 pp.

McKinnon, G. E., Steane, D. A., Potts, B. M. \& Valllancourt, R. E., 1999: Incongruence between chloroplast and species phylogenies in Eucalyptus subgenus Monocalyptus. American Journal of Botany 86: 1038-1046.

McKinnon, G. E., Vaillancourt, R. E., Jackson, H. D. \& PoTTS, B. M., 2001a: Chloroplast sharing in the Tasmanian eucalypts. Evolution 55: 703-711.

McKinnon, G. E., Vaillancourt, R. E., Tilyard, P. A. \& Potts, B. M., 2001b: Maternal inheritance of the chloroplast genome in Eucalyptus globulus and interspecific hybrids. Genome 44: 831-835.

MCKinnon, G. E., Jordan, G. J., Valllancourt, R. E.; Steane, D. A. \& PotTs, B. M., in press: Glacial refugia and reticulate evolution: the case of the Tasmanian eucalypts. Philosophical Transactions of the Royal Society of London - Series B: Biological Sciences.

Moran, G. F., Thamarus, K. A., Raymond, C. A., Qiu, D., Uren, T. \& Southerton, S. G., 2002: Genomics of Eucalyptus wood traits. Annales des Sciences Forestieres (Paris) 59: 645-650.

Mueller, F., 1879-84: Eucalyptographia: A descriptive Atlas of the Eucalypts of Australia and the Adjoining Islands. Government Printer, Melbourne. 10 parts.

Myburg, A. A., Grifin, A. R., Sederoff, R. R. \& Whetten, R. W., 2003: Comparative genetic linkage maps of Eucalyptus grandis, Eucalyptus globulus and their $\mathrm{F}_{1}$ hybrid based on a double pseudo-backcross mapping approach. Theoretical and Applied Genetics 107: 1028-1042.

Nesbitt, K. A., Potts, B. M., Valllancourt, R. E., West, A. K. \& REID, J. B., 1995: Partitioning and distribution of RAPD variation in a forest tree species, Eucalyptus globulus (Myrtaceae). Heredity 74: 628-637.

ORME, R. K., 1977: Eucalyptus globulus provenances. Third World Consultation on Forest Tree Breeding, 21-26 Mar. 1977. (CSIRO, Canberra) IUFRO International Symposium Canberra, Australia: 207-222.

Patterson, B., Vaillancourt, R. E. \& Potts, B. M., 2001: Eucalypt seed collectors: beware of sampling seed lots from low in the canopy! Australian Forestry 64: 139-142.

PhILlips, R. L. \& ReID, J. B., 1980: Clinal variation between Eucalyptus viminalis Labill. and E. dalrympleana Maiden. Australian Journal of Botany 28: 329-342.

PILIPENKA, F. S., 1969: [Hybridisation of eucalypts in the USSR]. Akademiya Nauk SSSR. Botanicheski Institut. Trudy 6th series. Introduktsiya Rastenii Zelende Stroitel'stvd 9: 5-68. (Translated by P. Auckland, CSIRO: Melbourne).

Poke, F., Valllancourt, R., Elliott, R. \& Reid, J., 2003: Sequence variation in two lignin biosynthesis genes, cinnamoyl CoA reductase (CCR) and cinnamyl alcohol dehydrogenase 2 (CAD2), Molecular Breeding 12: 107-118.

POTTS, B. M., 1988: The distribution and type locality of Eucalyptus cordata Labill. - an historical account. Papers and Proceedings of the Royal Society of Tasmania 122: 31-38.

POTTS, B. M., 1989: Population variation and conservation status of 
a rare Tasmanian endemic, Eucalyptus cordata. Tasmanian Forest Research Council Inc., Hobart: 140 pp.

POTTS, B. M. \& JACKSON, W. D., 1986: Evolutionary processes in the Tasmanian high altitude eucalypts. In Barlow, B. A. (Ed.): Flora and Fauna of Alpine Australasia. Ages and Origins, CSIRO, Melbourne: 511-527.

PotTs, B. M. \& PotTs, W. C., 1986: Eucalypt breeding in France. Australian Forestry 49: 210-218.

PotTs, B. M., PotTs, W. C. \& KantVIlas, G., 2001: The Miena cider gum, Eucalyptus gunnii subsp. divaricata (Myrtaceae): a taxon in rapid decline. Papers and Proceedings of the Royal Society of Tasmania 135: 57-61.

PotTs, B. M., \& ReID, J. B., 1985a: Variation in the Eucalyptus gunnii-archeri complex. I. Variation in the adult phenotype. Australian Journal of Botany 33: 337-359.

PotTs, B. M. \& ReID, J. B., 1985b: Variation in the Eucalyptus gunnii-archeri complex. II. The origin of variation. Australian Journal of Botany 33: 519-541.

PotTs, B. M. \& Reid, J. B., 1988: Hybridisation as a dispersal mechanism. Evolution 42: 1245-1255.

Potts, B. M., Volker, P. W., Tilyard, P. A. \& Joyce, K., (2000): The genetics of hybridisation in the temperate Eucalyptus. In Dungey, H. D., Dieters, M. J. \& Nikles, D. G. (Eds): Hybrid Breeding and Genetics of Forest Trees. Proceedings of QFRI/CRC-SPF Symposium, 9-14 April 2000, Noosa, Queensland, Australia. Queensland Department of Primary Industries, Brisbane: 200-211.

Pound, L. M., Wallwork, M. A. B., Potts, B. M. \& Sedgley, M., 2002: Self-incompatibility in Eucalyptus globulus ssp. globulus (Myrtaceae). Australian Journal of Botany 50: $365-372$.

PRYOR, L. D. \& JoHnson, L. A. S., 1971: A classification of the eucalypts. Australian National University Press, Canberra: $102 \mathrm{pp}$.

RaYmond, C. A., 2001: Genetics of Eucalyptus wood properties. Annals of Forest Science 59: 525-531.

RoDway, L., 1903: The Tasmanian flora. Government Printer, Hobart: $320 \mathrm{pp}$

RoDway, L., 1918: Tasmanian eucalypts. Proceedings of the Royal Society of Tasmania 1917: 10-20.

Sale, M. M., Potts, B. M., West, A. K. \& Reid, J. B., 1993: Relationships within Eucalyptus using chloroplast DNA. Australian Systematic Botany 6: 127-138.

Savva, M., PotTs, B. M. \& ReID, J. B., 1988: The breeding system and gene flow in Eucalyptus urnigera. In Knox, R. B., Sing, M. B. \& Troiani, L. F. (Eds): Pollination '88, Plant Cell Biology Research Centre, University of Melbourne, Melbourne: 176-182.

SCHILDER, G., 1988: New Holland: The Dutch discoveries. In Williams, G. \& Frost A. (Ed.): Terra Australis to Australia. Oxford University Press, Melbourne: 83-115.

Shaw, M. J., PotTs, B. M. \& Reid, J. B., 1984: Variation within and between Eucalyptus nitida Hook.f. and E. coccifera Hook.f. Australian Journal of Botany 32: 641-654.

SOMERVILle, J., 1964: History of Tasmanian Botany: 1642-1820. Unpublished manuscript, University of Tasmania.

Steane, D., Nicolle, D., Vaillancourt, R. \& PotTs, B., 2002: Higher level relationships among the eucalypts are resolved by ITS sequence data. Australian Systematic Botany 15: 49-62.

Steane, D. A., Byrne, M., Vaillancourt, R. E. \& Potts, B. M., 1998: Chloroplast DNA polymorphism signals complex interspecific interactions in Eucalyptus (Myrtaceae). Australian Systematic Botany 11:25-40.
Steane, D. A., Vaillancourt, R. E., Russell, J., Powell, W., Marshall, D. \& PotTs, B. M., 2001: Microsatellite variation in a forest tree, Eucalyptus globulus ssp. globulus (Myrtaceae). Silvae Genetica 50: 89-91.

Steane, D. A., West, A. K., Potts, B. M., Ovenden, J. M. \& REID, J. B., 1991: Restriction fragment length polymorphisms in chloroplast DNA from six species of Eucalyptus. Australian Journal of Botany 39: 399-414.

TAYLOR, H. G., 1973: The discovery of Tasmania. Cat \& Fiddle Press, Hobart: 177 pp.

Thamarus, K., Groom, J., Murrell, M., Byrne, M. \& Moran, G., 2002: A genetic linkage map for Eucalyptus globulus containing microsatellite and candidate gene loci and cambium specific espressed sequence tags (ESTs). Theoretical and Applied Genetics 104: 379-387.

ThOMAS, D. A. \& BARBER, H. N., 1974a: Studies on leaf characteristics of a cline of Eucalyptus urnigera from Mt Wellington, Tasmania. I. Water repellancy and the freezing of leaves. Australian Journal of Botany 22: 501-512.

ThOMAS, D. A. \& BARBER, H. N., 1974b: Studies on leaf characteristics of a cline of Eucalyptus urnigera from Mt Wellington, Tasmania. II. Reflection, transmission and absorption of radiation. Australian Journal of Botany 22: 701-707.

Turnbul., J., 1999: Eucalypt plantations. New Forest 17: $37-$ 52.

Turner, C., Wiltshire, R. J. E., Potts, B. M. \& Valllancourt, R. E., 2001: Variation in seedling morphology in the Eucalyptus risdonii Hook. f - E. tenuiramis Miq. complex. Australian Systematic Botany 49: 43-54.

Vaillancourt, R. E. \& JACKson, H. D., 2000: A chloroplast DNA hypervariable region in eucalypts. Theoretical and Applied Genetics 101: 473-477.

Vaillancourt, R. E., Potts, B. M., Manson, A. \& Reid, J. B., 1994: Detection of QTL's in a Eucalyptus gunnii $\mathrm{x} E$. globulus $\mathrm{F}_{2}$ using a RAPD linkage map. Proceedings of the International Symposium of Wood Biotechnology (ISWB), Tokyo, Japan, August 31-Sept 1, 1994. Tokyo, Japan: 63-70.

VOLKER, P., 2002: Quantitative genetics of Eucalypus globulus, E. nitens and their $\mathrm{F}_{1}$ hybrid. Unpublished $\mathrm{PhD}$ thesis. Univeristy of Tasmania, Hobart.

WALKER, J. B., 1891: The discovery of Van Diemen's Land in 1642; with notes on the localities mentioned in Tasman's journal of the Voyage. Government Printer, Hobart: $16 \mathrm{pp}$.

Wallis, H., 1988: Java la Grande: The enigma of the Dieppe maps. In Williams, G. and Frost, A. (Eds): Terra Australis to Australia. Oxford University Press, Melbourne: 39-80.

Williams, D. R., PotTs, B. M. \& BlaCK, P. G., 1999: A single visit pollination method for Eucalyptus globulus. Australian Forestry 62: 346-352.

Williams, J. E. \& WoINarski, J. C. Z., 1997: Eucalypt Ecology: Individuals to Ecosystems. Cambridge University Press, Cambridge: 430 pP.

Williams, K. \& PotTs, B. M., 1996: The natural distribution of Eucalyptus species in Tasmania. Tasforests 8: 39-164.

WiLson, R. C., 1975: Robert Gordon Lindsay Brett — some reflections on his life and work as an educationist in Tasmania. Tasmanian Journal of Education 9: 58-59.

Wiltshire, R. J. E., PotTs, B. M. \& Reid, J. B., 1991: A paedomorphocline in Eucalyptus: Natural variation in the $E$. risdoniilE. tenuiramis complex. Australian Journal of Botany 39: 545-566.

Wiltshire, R. J. E., PotTs, B. M. \& Reid, J. B., 1992: A paedomorphocline in Eucalyptus: II. Variation in seedling mor- 
phology in the E. risdonii/tenuiramis complex. Australian Journal of Botany 40: 789-805.

Wiltshire, R. J. E., POtTs, B. M. \& Reid, J. B., 1998: Genetic control of reproductive and vegetative phase change in the Eucalyptus risdonii-E. tenuiramis complex. Australian Journal of Botany 46: 45-63.

WILTSHIRE, R. J. E. \& ReID, J. B., 1987: Genetic variation in the Spinning Gum, Eucalyptus perriniana F. Muell. ex Rodway. Australian Joumal of Botany 35: 33-47.

Wood, M. S., Stephens, N. C., Allison, B. K. \& Howell, C. I., 2001: Plantations of Australia - A report from the National
Plantation Inventory and the National Farm Forest Inventory. Bureau of Rural Sciences, Canberra: $72 \mathrm{pp}$.

WRIGHT, S., 1948: On the role of directed and random changes in gene frequency in the genetics of populations. Evolution 2: 279-294.

ZACHARIN, R. F., 1978: Emigrant eucalypts: gum trees as exotics. Melbourne University Press, Melbourne:137 pp.

(accepted 24 November 2003) 